\title{
From Pagan Temple to Church in Late Antiquity Palestine A View from Hippos-Sussita
}

\author{
MARIUSZ BURDAJEWICZ
}

\begin{abstract}
The destruction of pagan temples and/or their conversion to churches during the Late Antiquity have been the subject of much study and speculation. For a long period debate on this topic was shaped chiefly by various literary accounts, while archaeological data were somewhat neglected. The purpose of this article is to provide some observations on this issue from a strictly archaeological perspective. The occasion for this are the results of the Polish excavations at Hippos-Sussita. A large basilica that has been unearthed there was built directly on the remains of an earlier Roman temple. The first section of the paper presents elements of the Roman temple which have been identified in various parts of the church area. The second part briefly discusses the other sites in Palestine which have yielded archaeological evidence of churches built over pagan temples.
\end{abstract}

Keywords: Palestine, Late Antiquity, Early Christianity, temple conversion, church, Hippos-Sussita

Mariusz Burdajewicz, Institute of Mediterranean and Oriental Cultures, Polish Academy of Sciences, Warszawa; mariuszali@yahoo.fr

One of the very intriguing and much discussed research questions in scholarship related to Late Antiquity and Early Christianity is the phenomenon of temple-destruction and/or transformation of pagan sacred buildings and cult places into churches and sites of Christian worship. This phenomenon also occupies a fairly large place in ancient literary sources. In respect to Palestine it is enough to mention authors such as Eusebius (Vita Constantini), Sozomen (Historia Ecclesiastica), and, above all, Mark the Deacon (The Life of St. Porphyry). The fate of pagan temples in Gaza vividly described by Mark the Deacon usually plays a crucial role in modern scholarship concerning the phenomenon of the destruction of the temples and building new churches in their places as a symbolic manifestation of the triumph of Christianity over Paganism. While reading the works of these and other ancient historians and writers, which still constitute the main source of our knowledge on this subject, one may gain the irresistible impression that: 
- the relatively rapid propagation of the new religion, especially after the official and legal triumph of Christianity in AD 313 ('Edict' of Milan), brought pagan religions, beliefs, cults and worships to a dramatic and abrupt end;

- the process of Christianization and abolition of pagan cults was inseparable from numerous violent acts directed against the material infrastructure of Paganism, viz. cult statues and images, temples, sanctuaries and other places of non-Christian worships and cults;

- it was a common phenomenon which affected the vast territory of the Roman Empire, both its Western and Eastern parts.

Such a picture of the final days of Paganism was outlined over seventy years ago by Friedrich Deichman in his fundamental work 'Frühchristliche Kirchen in antiken Heiligtümern'. His concept for a long time guided other scholars dealing with the issues of Christianization in Late Antiquity. A seminal article on bishops and their influence on the destruction of the temples published by Garth Fowden clearly points to such a trend of scholarship. ${ }^{2}$

In recent years, however, several new studies have appeared (where more attention is paid to archaeological evidence), which show that the picture of the Late Antique world as presented by Deichman and his followers seems to be too simplified, to say the least. ${ }^{3}$ It becomes more evident that Christian sources, which abound with description of violent events like the demolition, destruction and finally transformation of several temples and sanctuaries into places of victorious Christian faith, have a limited value as historical documents, and usually cannot be verified. In some cases the ancient accounts can even be disproved when confronted with archaeological evidence. This is the case, for example, with the temple-destructions at Heliopolis (Baalbek) made by Christian protagonists and referred to by Eusebius (Vita Constantini 3.58) and in particular by Sozomen (Historia Ecclesiastica 5.10). According to the latter writer, Constantine ordered the destruction of the temple of the immoral Aphrodite and then erected a church upon its ruins. The problem is, however, that no traces of any church have ever been found in the ruins of this temple. ${ }^{4}$

Below, we will attempt to make a contribution to this discussion by presenting relevant evidence from the Polish excavations from Hippos-Sussita, conducted between 2000 and 2008. ${ }^{5}$

\section{TEMPLE AND CHURCH AT HIPPOS-SUSSITA}

Hippos-Sussita is located on the eastern shore of the Sea of Galilee, c. $2 \mathrm{~km}$ from the lake. The remains of the city are situated on the top of a flat diamond-shaped hill, Qal'at

\footnotetext{
${ }^{1}$ Deichmann 1939.

${ }^{2}$ Fowden 1978: especially 78 (discussion on destruction of urban temples).

${ }^{3}$ Among others: Hahn, Emmel, Gotter (Eds) 2008 (include several articles related to this topic); Lavan 2011; Busine 2008; Bayliss 2005.

${ }^{4}$ It should be noted, however, that a large basilica with three apses was built on the terrace of the temple of Baal, probably in the middle of the fifth century. The basilica covered the steps leading to the temple and the two altars situated in the western part of the courtyard (Emmel, Gotter, Hahn 2008: 1-2, and see further references therein).

${ }^{5}$ For the summary of the excavations, see: Młynarczyk, Burdajewicz 2013.
} 
el-Husn ('fortress of the horse'), rising c. 350m above the water level. The city, founded at the beginning of the Hellenistic period under the name of Hippos, during the Seleucid rule was known as Antiochia Hippos. After the Roman conquest of the area in 64/63 BC, Hippos became one of the cities belonging to the Decapolis alliance ('the Ten Cities'). These cities were important cultural and political centers of the Greco-Roman world in the East. Petros, a bishop of Hippos, participated in the council of Seleucia in AD 359, which means that at least from the middle of the fourth century AD the city was an episcopal see. The city flourished during the Byzantine period and at that time was also known as Sussita (the Aramaic version of the Greek Hippos) or Susiya (the Arabic version). The city was destroyed during the catastrophic earthquake of $\mathrm{AD} 749$ and never rebuilt. ${ }^{6}$

In 2000, an international Hippos-Sussita archaeological project was launched. The activity of the Polish team has been concentrated in the very center of the city, in the place which was soon to become known as the North-West Church complex (thereafter NWC). During the nine seasons of excavations a large church with atrium and annexes has been fully unearthed. Before we move on to the main topic, it is necessary to present in brief the main characteristics of the architectural development of the church. ${ }^{7}$

The church was built at the end of the fifth century as a mono-apsidal basilica (inner dimensions: $20.8 \times 13.7 \mathrm{~m})$. It was accessible from the atrium through three entrances: a wide central door and two lateral, slightly smaller ones. The interior was divided into a nave and two aisles by two rows of columns (six to each row). The apse with a synthronon was flanked by two slightly trapezoidal sacristies (pastophoria). The presbytery (bema) was contained within the nave and corresponded to the length of two intercolumnia; it raised two or three steps above the floor of the nave. Two wings, to the north and south of the church, were accessible by lateral entrances from the aisles. The atrium of the church $(22 \times 22 \mathrm{~m})$ contained a spacious courtyard paved with rectangular and square basalt flagstones, surrounded by four porticoes with six columns to a side (Fig. 1a).

In the next phase the northern sacristy was cut off from the aisle by a wall. This new small room, which probably served as a skeuophylakion or treasury, could be accessed only through a low side door from the apse. At the eastern end of the northern aisle a small apse was built, and the entrance to the northern annex was blocked. At the next stage of this phase the chancel area was extended to embrace the eastern ends of both aisles assuming a T-shaped outline (Fig. 1b).

In the Umayyad period an important change took place in the northern wing, where, upon the earlier rooms, a winery complex was created.

The church functioned until the very end of the city's existence (AD 749), although some of its parts went out of use or their original function had been changed.

\footnotetext{
${ }^{6}$ On the geography, history, research history and bibliography of the site, see: Segal 2013.

${ }^{7}$ For the most comprehensive report to date, and bibliographical references to earlier publications on the NWC, see: Młynarczyk, Burdajewicz 2013.
} 

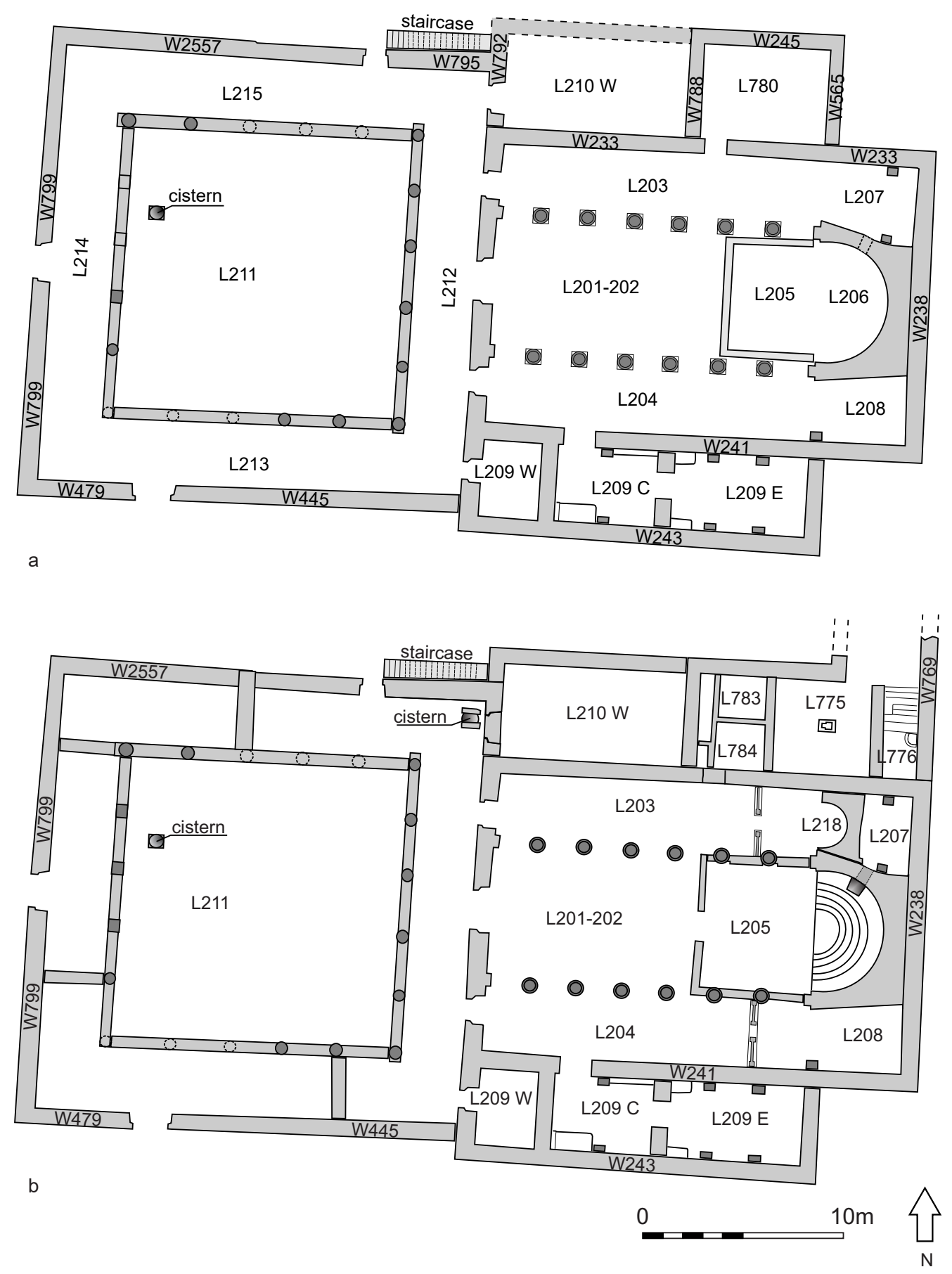

1. Schematic plan of the NWC: a. Phase I, sixth century; b. Phase II, seventh century (Drawing: M. Burdajewicz). 

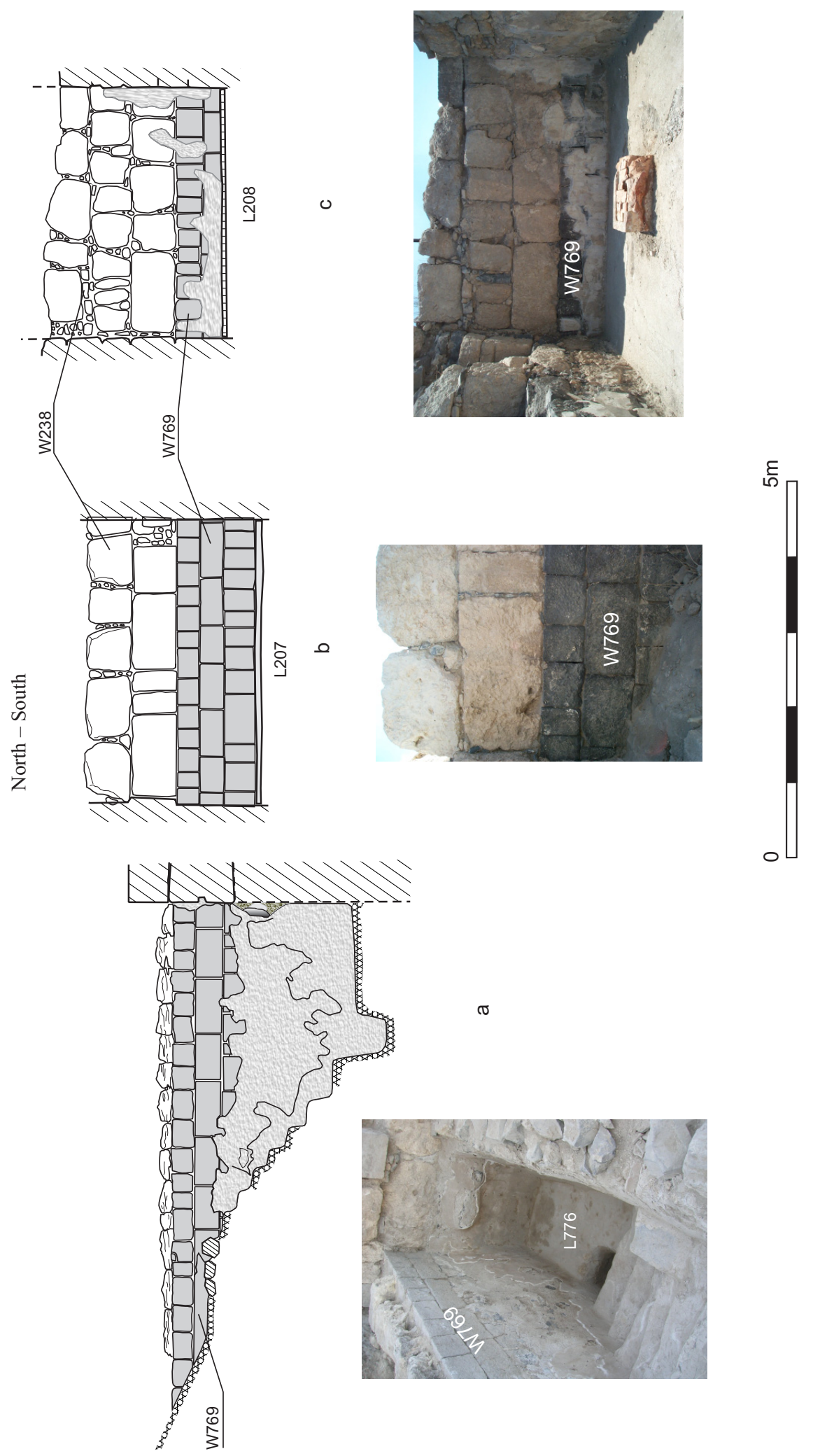

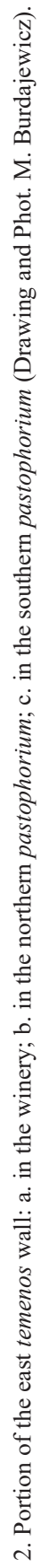




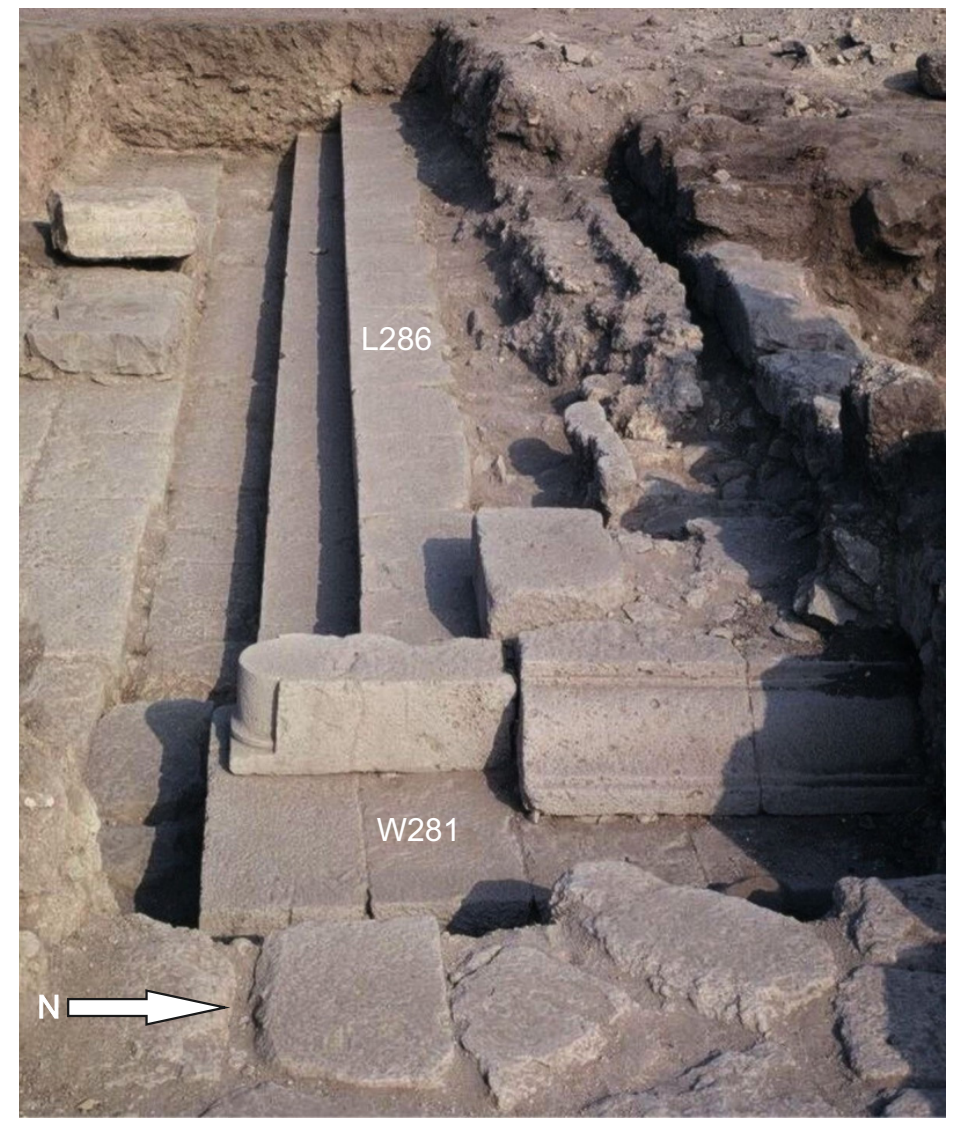

3. Basalt podium of Roman temple as seen from the east (Phot. J. Młynarczyk).

Bearing in mind the outline of the church's architectural development, we can proceed to the details concerning the pre-church constructions in this location. In the second season of excavations (2001) it became clear that the church had been partially built on the remains of an earlier building. This issue appeared when the rectangular room (L207) of the northern sacristy concealed behind the northern apse was completely uncovered. ${ }^{8}$ Its eastern wall (W238) was composed in fact of two walls, one upon the other, differing in construction methods and building materials. Three bottom courses were made of neat basalt ashlars, arranged in alternating layers of headers, stretchers, and headers again (W769). On top of that, two courses of huge limestone blocks have been preserved, but laid in a rather chaotic order (W238) (Fig. 2b).

An even more important discovery, which in some way determined the future strategy of the exploration of the NWC, was that of an entrance part of an earlier building. At the distance of $c .7 .5 \mathrm{~m}$ to the south of the southern wing of the church and parallel to it, a basalt podium consisting of three long steps between two antae was found (Fig. 3). In front of

\footnotetext{
${ }^{8}$ Młynarczyk, Burdajewicz 2001: 10.
} 

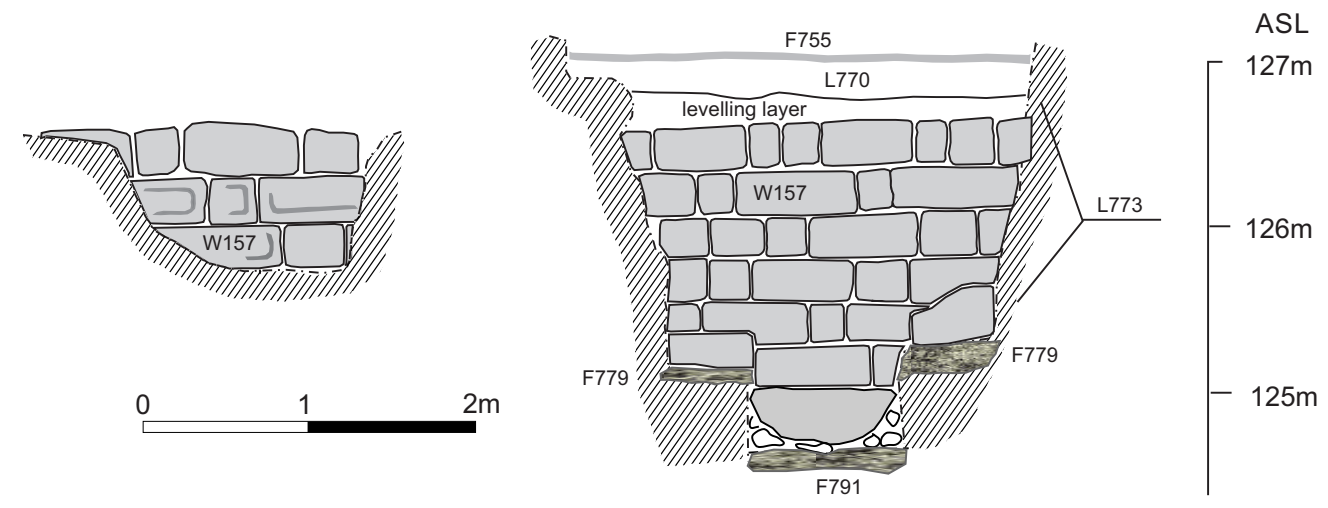

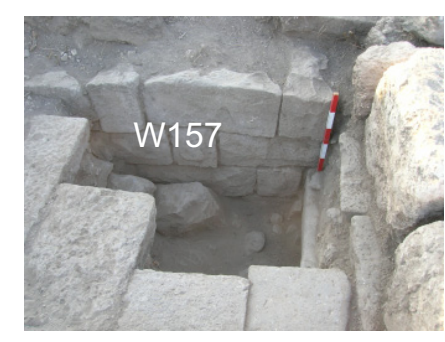

a

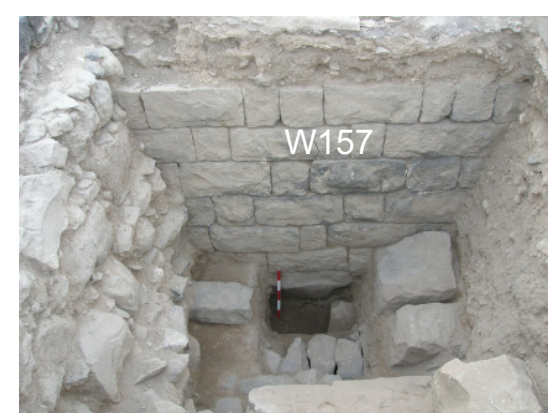

b

4. Portion of the west temenos wall: a. beneath the atrium; b. beneath the southern portico of the atrium (Drawing and Phot. M. Burdajewicz).

this podium was a pavement of carefully laid rectangular basalt slabs. The identity of the building once standing on the podium was unclear at that time, but it was evident that this was an important, monumental structure destined to occupy a dominant position. It was also obvious that this structure continued to the north, that is towards the NWC, and also that it preceded the construction of the church. ${ }^{9}$

During the subsequent seasons of excavation several trial pits were opened within the area of the church to locate the outline of this building. At the same time, the excavations revealed two other portions of the basalt wall discovered in 2001 in the northern skeuophylakion. One of them constituted the lower part of the eastern wall of the southern pastophorium (Fig. 2c); another one was found during the exploration of the northern winery (Fig. 2a).

A parallel north-south basalt wall (W157), of the same construction type as the eastern one, was also located in three other places beneath the atrium. A trial pit was opened in the western part of the southern portico of the atrium, in the place between a preserved part of

\footnotetext{
${ }^{9}$ Młynarczyk, Burdajewicz 2002: 26-27, Figs 43-45.
} 


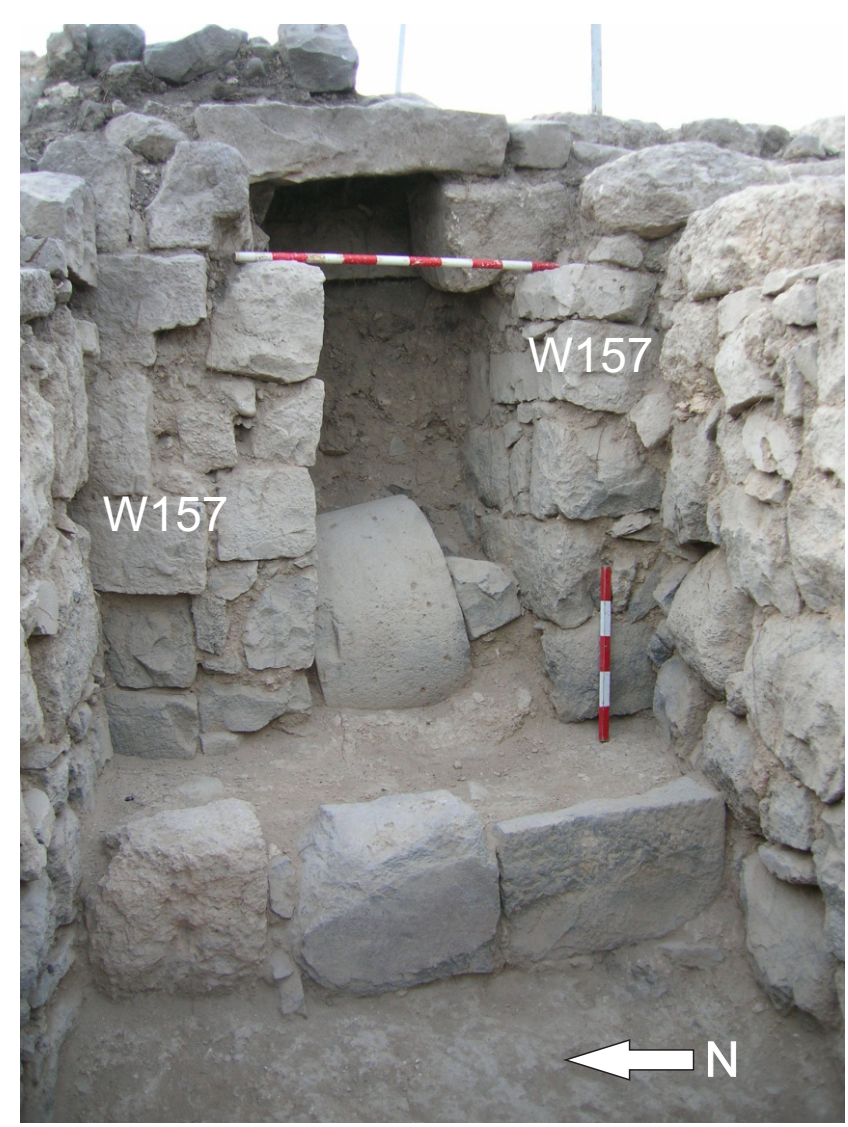

5. Portion of the west temenos wall in the cellar (Phot. J. Młynarczyk).

a mosaic floor and a basalt-paved walkway corresponding to the southern entrance. Under the mosaic floor was a thick leveling layer connected with the construction of the stylobate of the southern portico. Beneath this level a section of a basalt wall and its foundation was exposed (Fig. 4b). The continuation of this wall was also found in a small trial pit in the center of the courtyard (Fig. 4a). Finally, a third portion of this wall was identified during the exploration of the so-called cellar, in the northern portico of the atrium (Figs 5, 11). Both the eastern and western basalt walls, as we know it presently, constituted parts of the precinct wall of a Roman temenos.

Only small portions of the eastern and northern portico stylobates of the temenos could be found during the excavations of the NWC. One of them (W565) was exposed in a stratigraphical trench opened inside the main chancel area, on the east-west axis of the bema (Fig. 6). The wall, apparently pre-dating the construction of the church, also constitutes the western wall of the apse. ${ }^{10}$ Its northward continuation was noted under the slabs of the treading platform (Fig. 7) of the winery and outside of it. ${ }^{11}$

\footnotetext{
${ }^{10}$ Młynarczyk, Burdajewicz 2003: 32.

${ }^{11}$ Młynarczyk, Burdajewicz 2006: 57-58.
} 


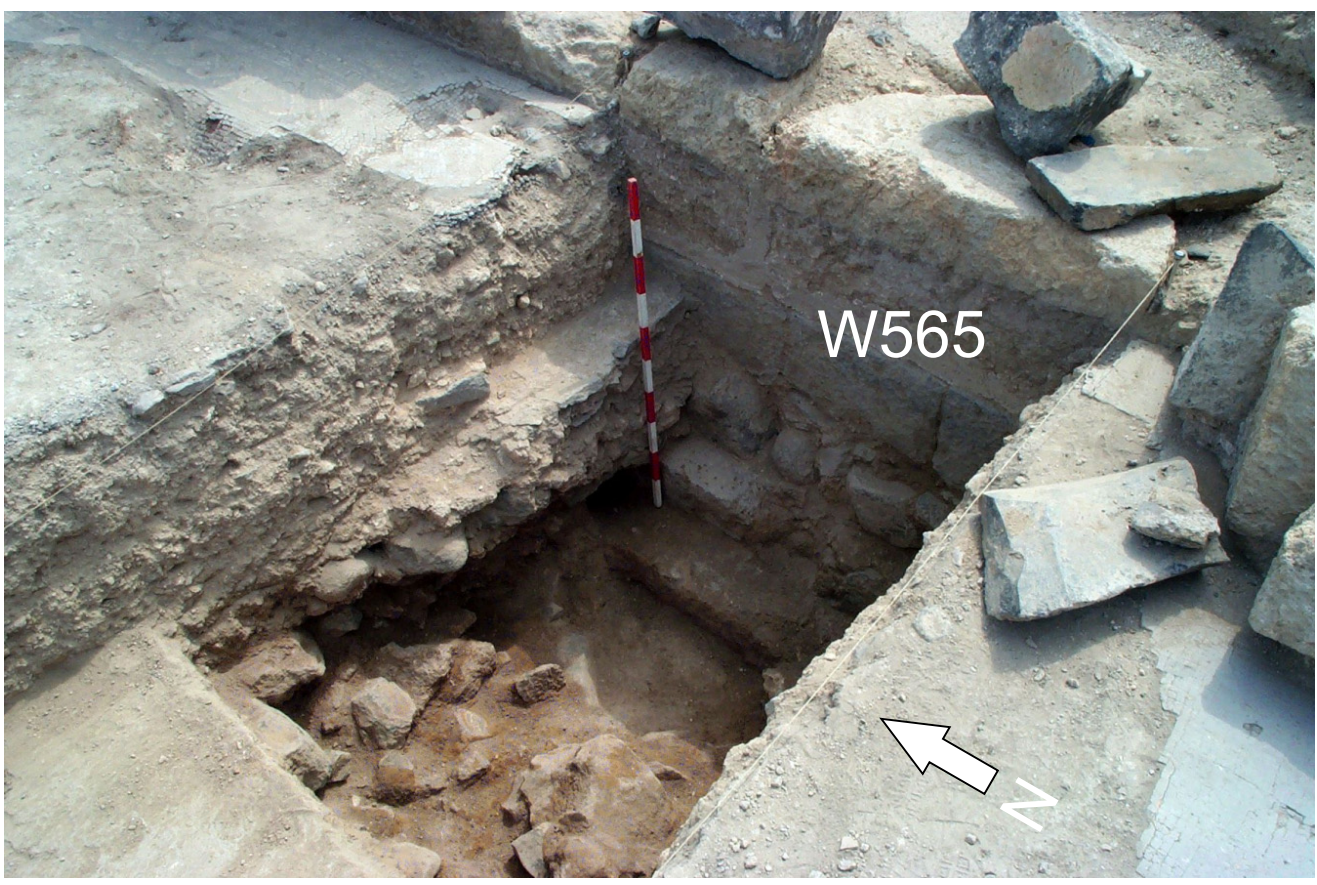

6. Trial pit in the main chancel area (Phot. J. Młynarczyk).

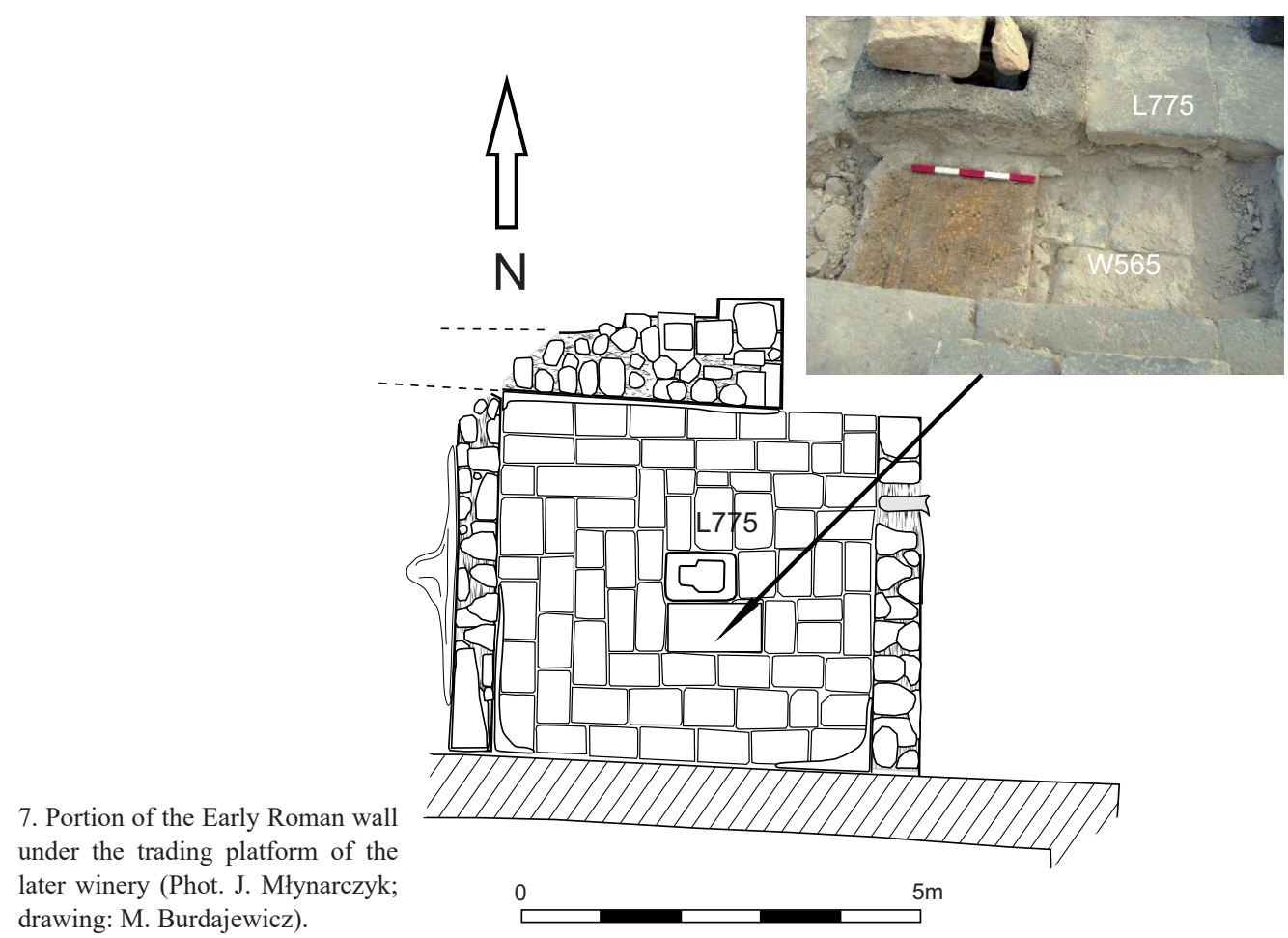




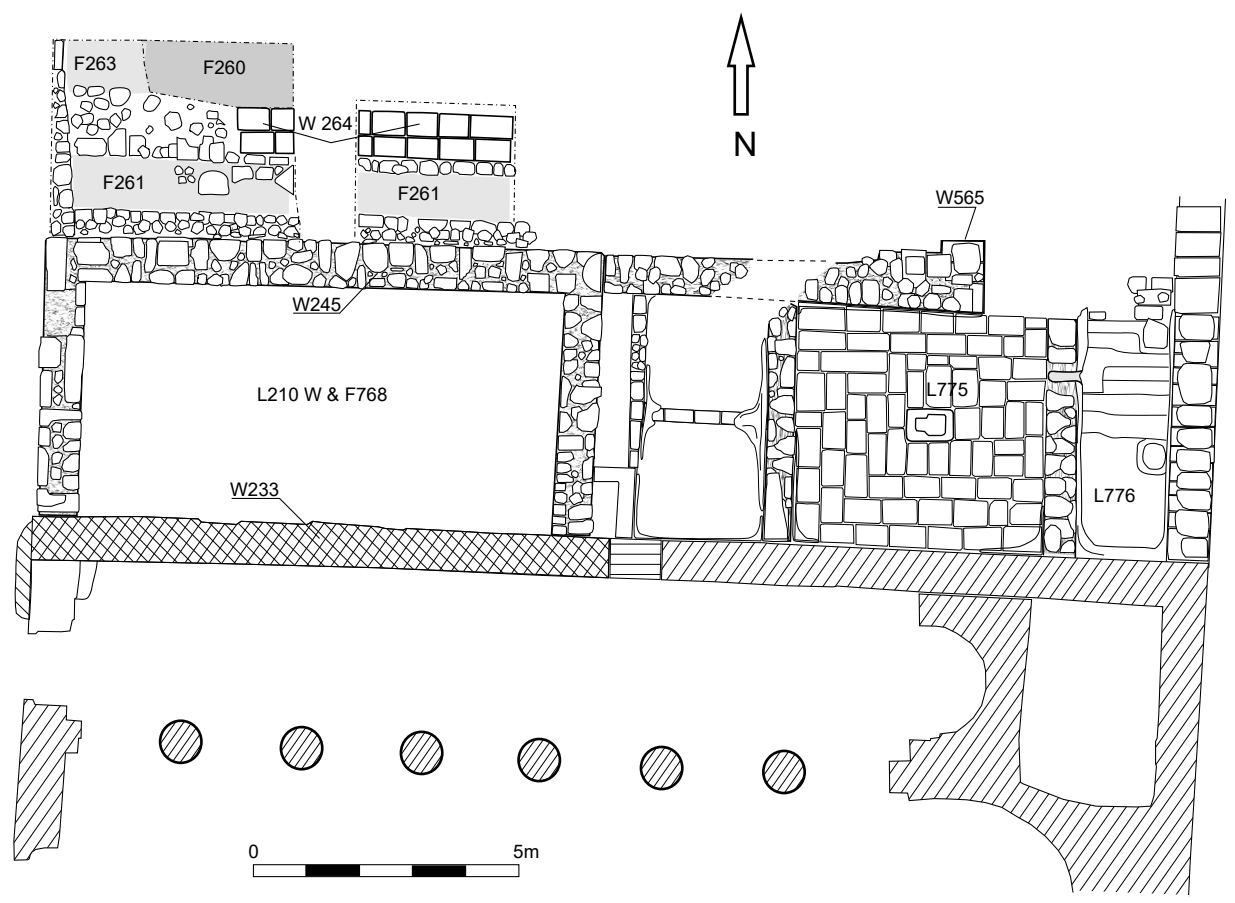

8. Plan of the northern wing of the NWC (Drawing: M. Burdajewicz).

A stratigraphical test trench which was opened outside the northern wing of the church, revealed the longest and best preserved portion of the northern stylobate (W264). It is situated $6.9 \mathrm{~m}$ from the northern wall (W233) of the church and is composed of two contiguous rows of limestone slabs, $0.85 \mathrm{~m}$ wide. The slabs are laid on a wider foundation of irregular stones. The walking level of the temenos (F263 and F261) was identified to the south and to the north of the stylobate (Fig. 8). ${ }^{12}$

As for the cella, some of its walls were re-used during the construction of the church. The best example illustrating this process is the northern wall of the church (W233). In fact, it consists of two different parts: the rear (northern) wall of the cella (10.70m long) reused in extenso, and its later Byzantine eastward extension (Fig. 9).

A relatively large portion of the cella is visible in the western wall of the church, especially in a part of W298 that was adapted as a bench in front of Room 209 W (the so-called mortuary chamber) (Fig. 10). Another section of this kind of bench runs inside Room 209 W, parallel to its southern wall. This bench (W293) is built of two layers of limestone blocks and resembles an exedra with curved ends. In fact, the eastern end of the bench protrudes from the western wall in the first diakonikon room (L209 C). ${ }^{13}$

\footnotetext{
${ }^{12}$ Młynarczyk, Burdajewicz 2001: 12, Fig. 47; 2005: 45.

${ }^{13}$ Młynarczyk, Burdajewicz 2004: 63-64.
} 


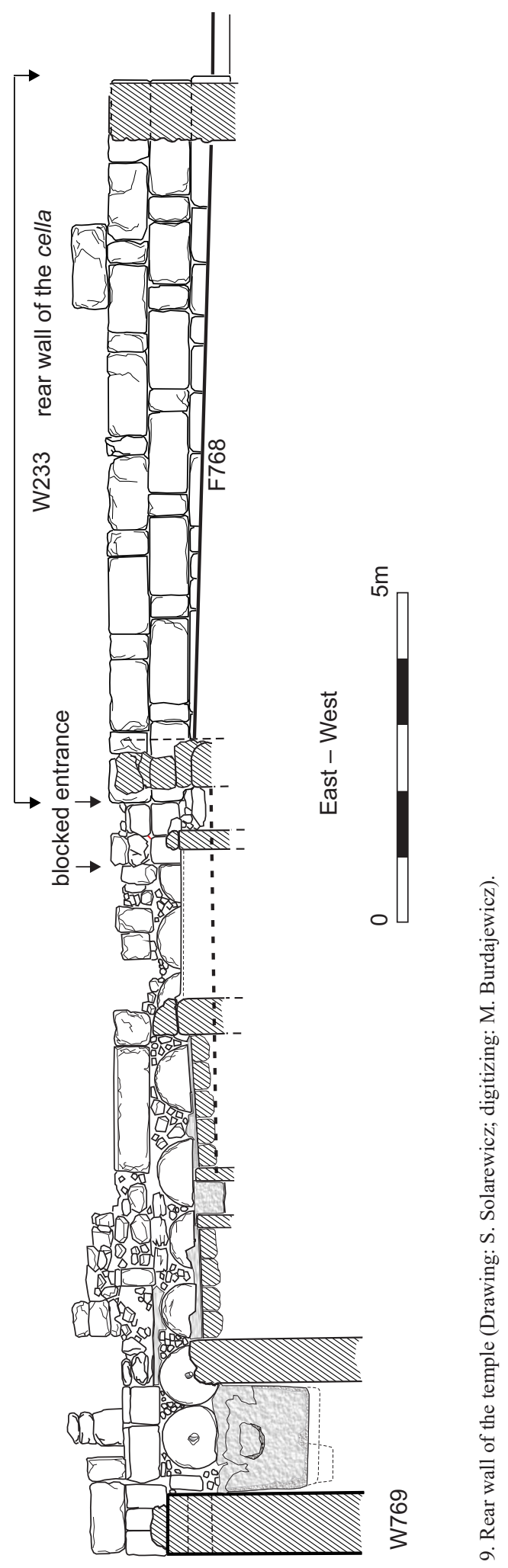




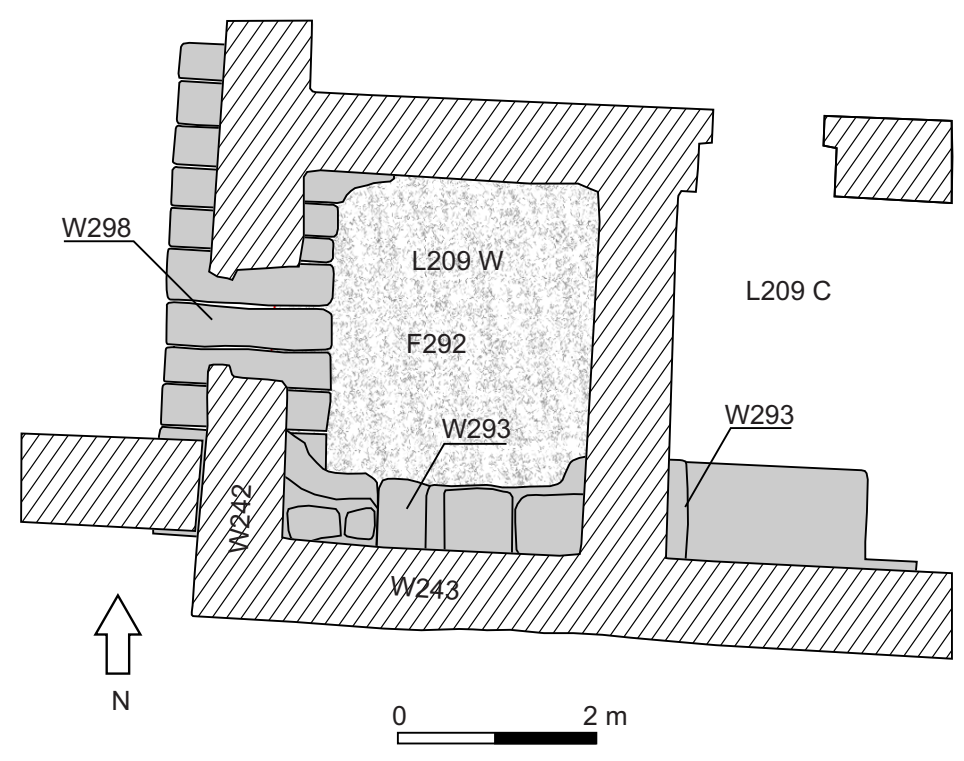

10. South-western part of the church with elements (marked in grey) of the Early Roman temple (Drawing: M. Burdajewicz).

The remains of the eastern wall of the cella are also visible in the second diakonikon Room 209 E. These are two large ashlars protruding above the Byzantine-period floor, adapted to serve as twin benches (Fig. 11).

As a result of all these discoveries, the plan of the Roman sanctuary can be reconstructed. It consisted of a cella of a prostylos tetrastylos in antis type, situated in the middle of a courtyard, and surrounded by porticoes and a peribolos wall (Fig. 11). ${ }^{14}$ The sanctuary, according to the earliest pottery findings associated with its foundations, can be dated to the Augustan or early Tiberian times. ${ }^{15}$ It is, however, much more difficult to determine when the sanctuary went out of use. According to Arthur Segal, the temple was perhaps destroyed in the earthquake of $\mathrm{AD} 363$ and never restored. ${ }^{16}$ In such a case, the following question remains unanswered for a while: what was the usage of this vast area between the end of the pagan cult and the construction of the church?

\section{ARCHITECTURAL DECORATION FROM THE ROMAN TEMPLE}

To complete the picture of the Roman temple, some limestone and stucco fragments of architectural decoration, which were found scattered throughout the area of the NWC, are worth mentioning. The analysis of their style leaves no doubt that they had to belong to

\footnotetext{
${ }^{14}$ See also: Segal 2013: 132, Fig. 154.

${ }^{15}$ For example: Młynarczyk 2004: 145.

${ }^{16}$ Segal 2013: 146.
} 


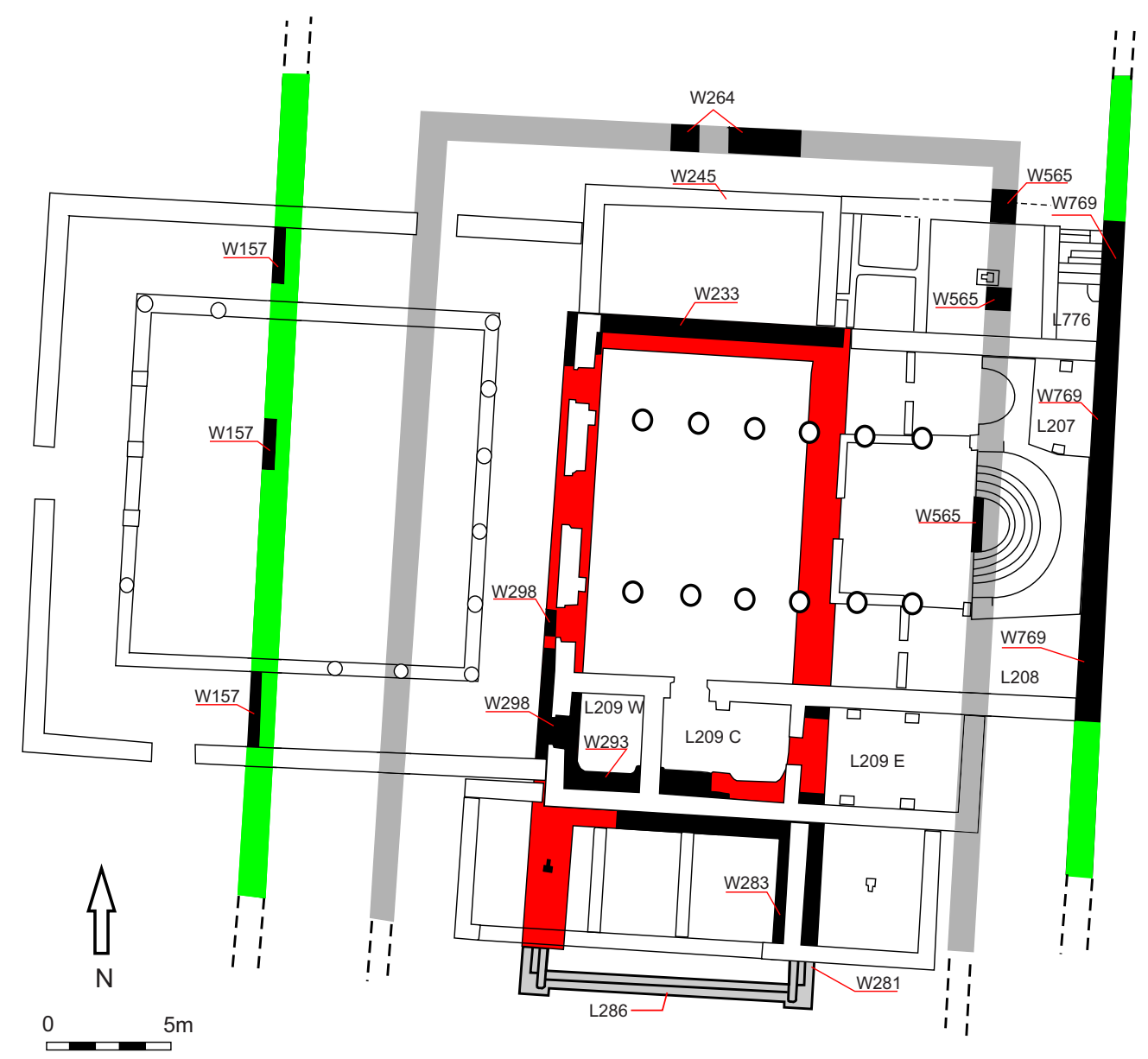

11. Plan of the remains of an Early Roman temenos and temple underlying the NWC complex; uncovered wall portions in black; presumed parts of the cella in red; presumed parts of the portico stylobates in grey; presumed parts of the peribolos wall in green (Drawing: M. Burdajewicz).

an earlier building erected in this area, that is to the Roman temple, the reconstructed plan of which we have just presented.

1. NWC 122, a limestone block, found on the treading floor of the northern winery. It is a part of a Doric frieze with tetraglyph and metope, the latter adorned with a vase resembling a volute crater (Fig. 12a).

2. NWC 131, a limestone block, found among debris of the church façade. Similarly, it is also part of the frieze consisting of a triglyph and fragments of two metopes, each of them decorated with a multi-petalled rosette; the original height of the block is not known (Fig. 12b). 

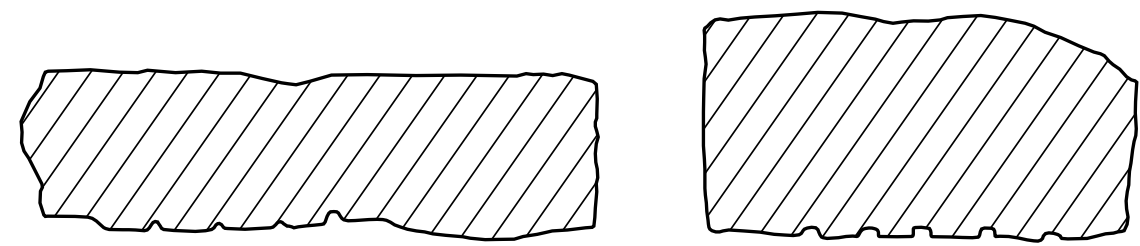

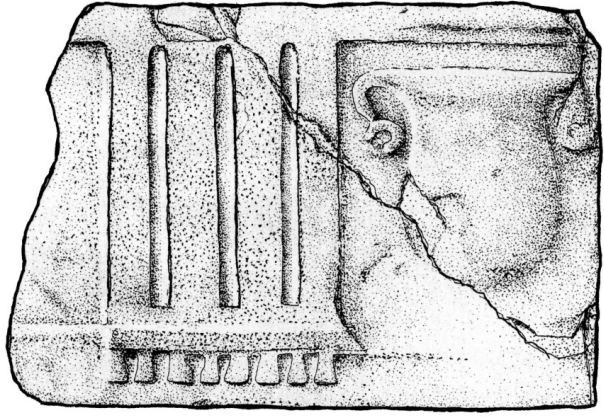

a
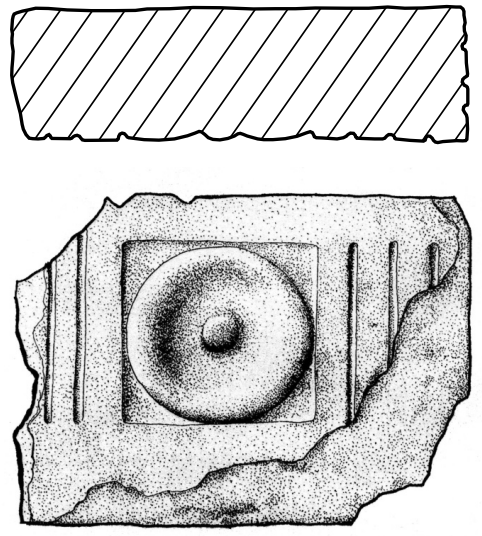

C

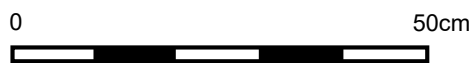

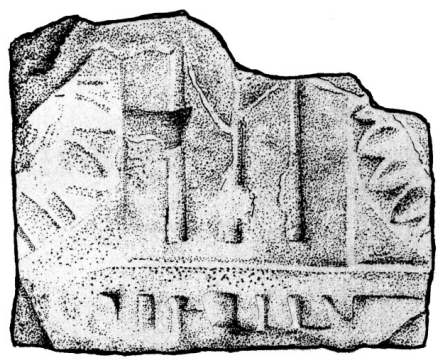

b
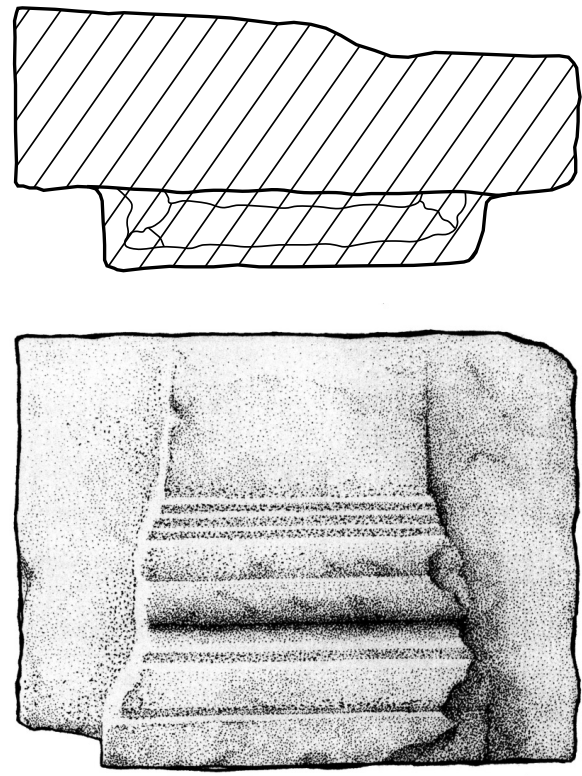

12a-d. Limestone fragments of architectural decoration of the sanctuary reused in the wall of the church (Drawing: J. Rądkowska, J. Szymański, M. Woźniak, M. Burdajewicz; inking: M. Burdajewicz). 
Block NWC 122 represents a variant of the Doric frieze, with a tetraglyph with eight guttae, instead of a classical triglyph with six guttae. The tetraglyph is $28 \mathrm{~cm}$ wide, the metope is $32 \mathrm{~cm}$, while the total height of the frieze amounts to $49 \mathrm{~cm}$. It is possible that this block as well as NWC 131 pertained to the frieze of the porticoes of the Early Roman temenos. A Doric frieze with tetraglyph is known also from the façade of the first century AD Tomb of the Germani in the eastern necropolis of Gadara. ${ }^{17}$

The rosettes of block NWC 131 are similar to the rosettes (consisting of 12 pointed petals) adorning the Doric frieze in Palaestra 101 of the Bath Building at Masada. ${ }^{18}$ Another close parallel can be found in the Monumental Building at Lower Herodion. ${ }^{19}$ Some rock-cut tomb façades in Jerusalem, dated to the end of the Second Temple period, were also adorned with comparable rosettes. ${ }^{20}$ Finally, one should mention the rock-cut tombs in Medain Saleh (Arabia), in which the Doric friezes were commonly decorated with such rosettes; they are dated the second quarter of the first century AD. ${ }^{21}$

3. NWC 155 found in the atrium is a corner block, also decorated of the Doric frieze (Fig. 12c); however, it must have belonged to another entablature of different dimensions than that from which block NWC 122 derived. In NWC 155 the height of the frieze is $40 \mathrm{~cm}$, the width of the triglyph (which lacks guttae) is $18 \mathrm{~cm}$ and that of the metope is $23 \mathrm{~cm}$. The metope is adorned with a phiale motif, which was very common in Palestinian and Arabian architectural decoration during the late first century $\mathrm{BC}$ - first century $\mathrm{AD}$, for example in Jerusalem and Petra. ${ }^{22}$ It is highly probable, that this block belonged to the entablature of the cella of the Roman temple.

4. NWC 146 was found among the blocks collapsed from the northern wall of the basilica. It is a limestone block preserving the base and a lower part of a pilaster (Fig. 12d). This kind of decoration could pertain to an outer face either of the precinct wall or of the cella, like, for example, pilasters rendered in stucco on the exterior walls of Qasr el Bint temple in Petra. ${ }^{23}$ Such architectural elements can be found in a number of Herodian-period structures, like the Monumental Building at Herodium, ${ }^{24}$ Machpelach Cave in Hebron, the sacred enclosure at Mamre. ${ }^{25}$

Apart from stone architectural elements, a few fragments of white stucco mouldings should be mentioned. Two of them with ovolo frieze (Fig. 13a-b) were unearthed in the debris above the northern winery treading floor. They are of high quality and find close parallels

\footnotetext{
${ }^{17}$ Peleg-Barkat 2011: 431.

${ }^{18}$ Foerster 1995: 123, no. 8, and 128; Figs 225:7, 232.

${ }^{19}$ Netzer 1999: 107, Fig. 153.

${ }^{20}$ Avigad 1950-1951: 100, Figs 5 (tomb in the street of the Prophet Samuel), 7 (Mugharet Umm el-'Amed).

${ }^{21}$ McKenzie 1990: Pls 2-6.

${ }^{22}$ Cf. Avigad 1950-1951: Fig. 8; McKenzie 1990: Pls 70-71 (Qasr el Bint temple, dated towards the turn of the era), 135-137 (other monuments of Petra, Group D, dated to 40-70 AD).

${ }^{23}$ McKenzie 1990: Pls 70, 73-74.

${ }^{24}$ Netzer 1981: Il. 69.

${ }^{25}$ Magen 2003: Figs 8 (Hebron), 12, 14.
} 


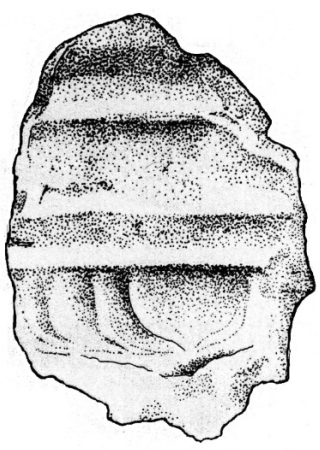

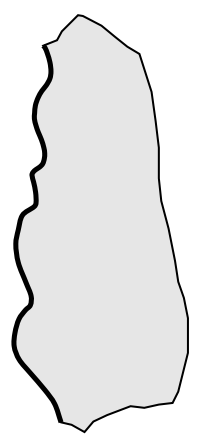

a

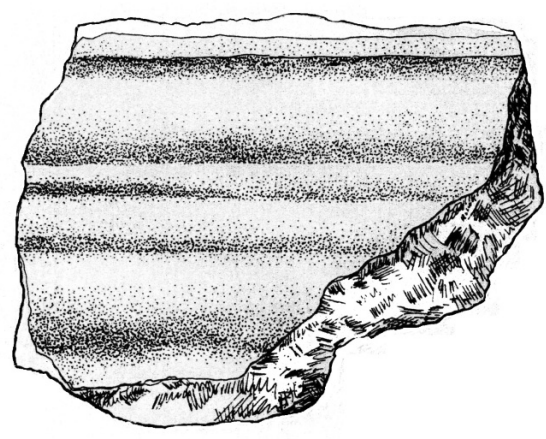

0

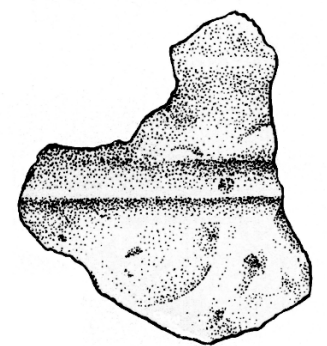

b

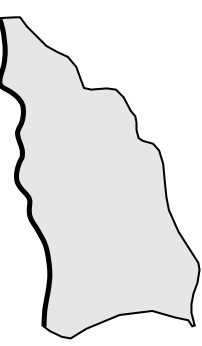

C

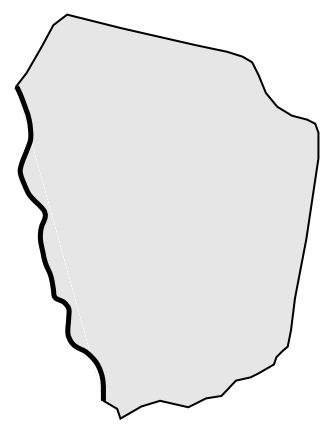

$10 \mathrm{~cm}$

13a-c. Stucco fragments of architectural decoration of the sanctuary reused in the wall of the church (Drawing: J. Morzycki, M. Burdajewicz; inking: M. Burdajewicz).

in the stuccoes from Herodian palaces, specifically, Tepidarium 106 and Apodyterium 105 at Masada (elements of coffered ceilings), Third Palace at Jericho (coffered ceiling) and its Sunken Garden (framing of a floral frieze), the fortress of Kypros (part of entablature), as well as from the palace at Machaerus. ${ }^{26}$ The third stucco piece (Fig. 13c) was found in the stratigraphical context connected with the western face of the temenos wall. It is difficult to determine its original position as a decorative element; possibly it constituted part of a projecting cornice. Many similar fragments of stucco decoration were found in Herod's Third Palace at Jericho. ${ }^{27}$

${ }^{26}$ Foerster 1995: 68-69, Figs 99-100 (Tepidarium 106) and Pl. XVII (Apodyterium 105); Netzer 1999 : Figs 65 (Third Palace, Jericho), 70 (Sunken Garden), 92 (Kypros); Vörös 2015: 350-351 (Machaerus).

${ }^{27}$ Peleg, Rozenberg 2008: 491-493, Type I, and see additional references therein. 


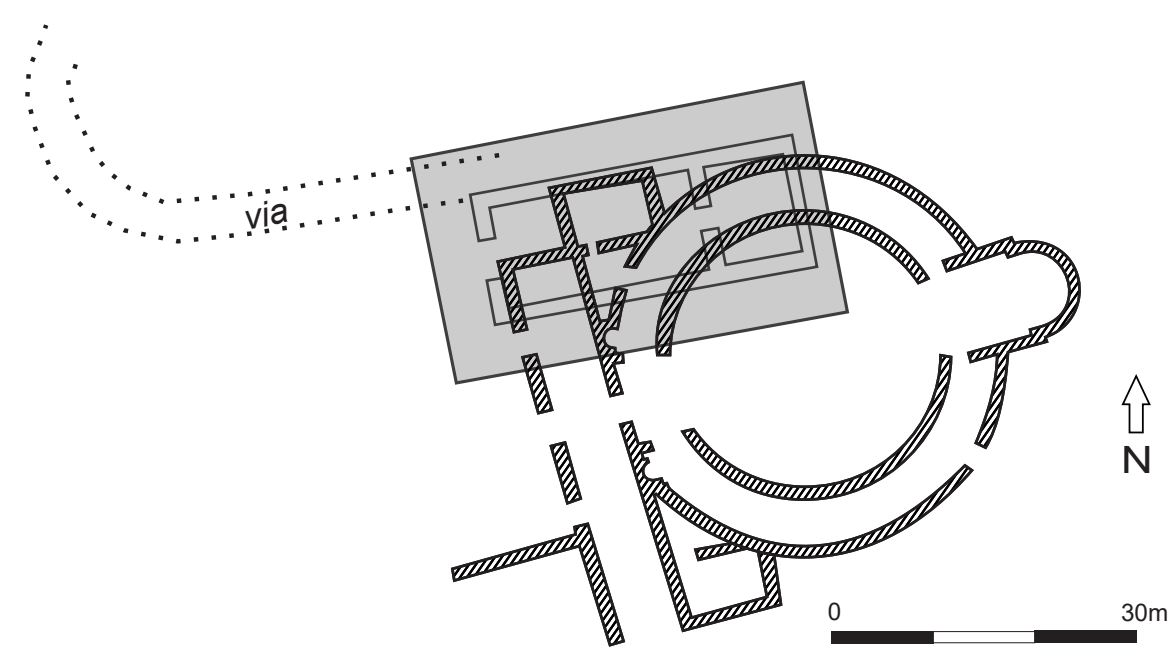

14. Temple of Zeus Akraios (marked in grey) and church (hatched) at Beth Shean (Drawing: M. Burdajewicz; based on: Mazor 2008: 1626).

\section{OTHER SITES IN PALESTINE}

\section{SCYTHOPOLIS/BETH SHEAN}

Scythopolis was one of the main cities of the Decapolis, flourishing from the Early Roman throughout the Byzantine and Umayyad periods. The inhabitants took advantage of the location of the city in the Jordan Valley, at the junction of roads connecting the Mediterranean coast and Gilead in Jordan, and on the way to/from Damascus in Syria along the Jordan Valley. The main civic and public buildings were constructed at the foot of a high tell, which dominated the landscape and functioned as the city's acropolis. ${ }^{28} \mathrm{On}$ its summit, probably during the first century AD, a monumental temple consecrated to Zeus Akraios ('Zeus of the High Mountain') was built (Fig. 14). Its remains are rather poorly preserved and consist of a rectangular stone podium (c. $22 \times 37 \mathrm{~m})$ and several architectural fragments, such as column drums and Corinthian capitals. No other Roman period structures have been found on the summit, which probably constituted part of the sacred area and therefore remained unoccupied. ${ }^{29}$ The date of destruction/abandonment of the temple remains unknown.

A round church was constructed no earlier than at the end of the fifth or beginning of sixth century AD, on the eastern part of the remains of the temple. ${ }^{30}$ Similarly as in the case

\footnotetext{
${ }^{28}$ During the Late Bronze Age the tell served both as administrative center (of Egyptian administration) and the main cult place with temples (cf. Mazar 2006: 28-29).

${ }^{29}$ Mazar 2006: 40; Rowe 1930: 44-45.

${ }^{30}$ Contrary to the excavators dating to AD 431-438: Nocera 2013: 18. For the excavations, see: Fitzgerald 1931: 18-30; Rowe 1930: 43-45.
} 
of the Roman temple, the church was accessible from the north-west by a road leading up from the civic center situated at the foot of the tell. The church was built on a central plan consisting of a rotunda (c. $39 \mathrm{~m}$ in diameter), ambulatory/cloister, a projecting apse on the east and a narthex/portico with a rectangular atrium on the west. The inner stylobate supported columns, of which nine shafts and seventeen capitals were found in the surrounding area. Six large Corinthian capitals have been identified as spolia from a building of the third to fourth century AD (possibly from the temple of Zeus Akraios). Since the walls of the church appear to be rather thin (only $1 \mathrm{~m}$ wide), as compared with other known Christian rotundae, it has been suggested that only ambulatory had a roof resting on arcades, with central space open to the sky.

\section{SEPPHORIS/DiocAESAREA}

Sepphoris, a city which, according to Josephus Flavius, was the 'pearl of all Galilee' (Antiquities 18.2.1) profited, like Beth Shean, from its geographical location, specifically, at the junction of roads between Mediterranean coast (Akko-Ptolemais) and the Sea of Galilee on the one hand, and between the north and south due to the branch road connecting the city with the famous ancient trade and military road via maris. ${ }^{31}$ The beginnings of the city's splendor goes back to $57 \mathrm{BC}$, when it was made by Gabinius, the Roman proconsul of Syria, a center of one of the five administrative districts (Josephus, War 1.170; Antiquities 14.91). The extensive excavations have shown that the city, despite its prevailing Jewish population, was planned and built according to Roman town-planning traditions. In Hadrian's time (AD 117-139), the name Sepphoris was replaced by that of Diocaesarea (that is: City of Zeus and of the Emperor), a gentile administration was installed, and a Roman (i.e. pagan from the Jewish point of view) temenos, with a temple, was built. This sacred complex is located in the south-eastern part of the Lower City, near the intersection of decumanus and cardo, the two main colonnaded streets (Fig. 15).

Access to the temenos from the decumanus was by means of a monumental entrance with four sizeable columns, with a wider intercolumniation in the center. The space between the temenos entrance and the temple was paved with stones, the rest of the courtyard floor was plastered.

The temple, of which only fragments of the podium have been preserved (24 x 12m), was built south of the center of the courtyard, with its façade facing north-east. Three steps between the two antae were also found. According to excavator Zeev Weiss, the temple represented tetrastylos prostylos type, with four columns in the façade and semicircular engaged columns in the walls of the naos. ${ }^{32}$

The temple was abandoned in the mid-fourth century AD, and after an intermediate phase of occupation, the nature of which remains unknown, the church was built directly on the ruins of the Roman temple in the late fifth or early sixth

\footnotetext{
${ }^{31}$ On the city's history and archaeological excavations, see: Weiss 1993 and 2008.

${ }^{32}$ Weiss 2010: 206.
} 


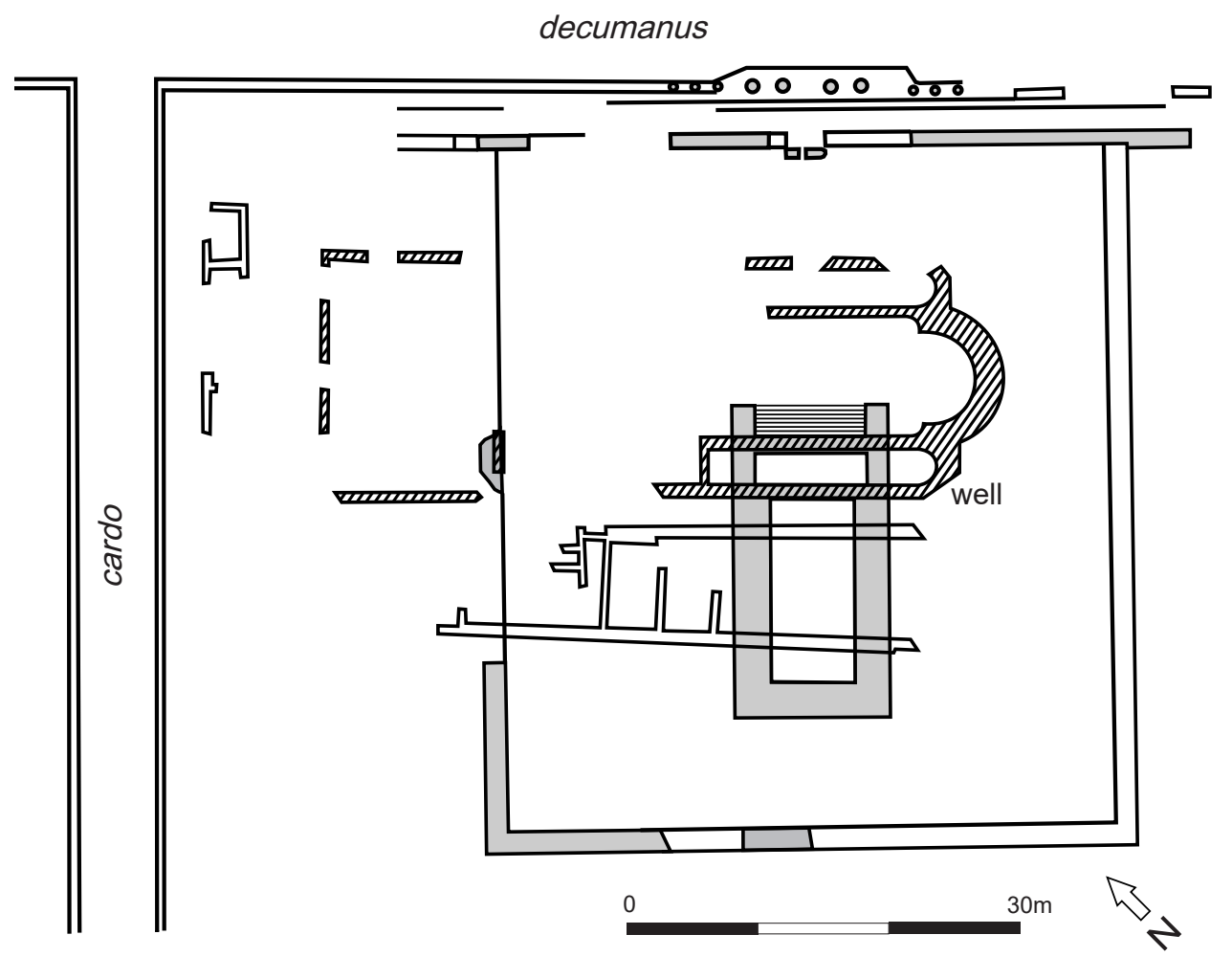

15. Temple (marked in grey) and church (hatched) at Sepphoris (Drawing: M. Burdajewicz; based on: Weiss 2010: Fig. 11).

century $\mathrm{AD} .{ }^{33}$ The remains of the church, which is only partially exposed, are in a very poor state of preservation. However, it is evident that the church $(c .62 \times 29 \mathrm{~m})$ represents a tri-apsidal basilical plan with a nartex and atrium $($ c. $25 \times 27 \mathrm{~m})$ to the west. It is built perpendicularly to the remains of the Roman temple, and oriented to the south-east, an alignment dictated by the existing urban plan. Access to the atrium was directly from the cardo.

Due to the poor state of preservation and the lack of reliable stratigraphical references, the date of abandonment and/or destruction of the church, remains unknown.

\section{DOR/DORA}

The harbor town, lying on the coast to the north of Caesarea, during the Byzantine period was an important administrative and also - as an episcopal see - a religious center. It was

${ }^{33}$ Weiss 2010: 212-214; 2015. 


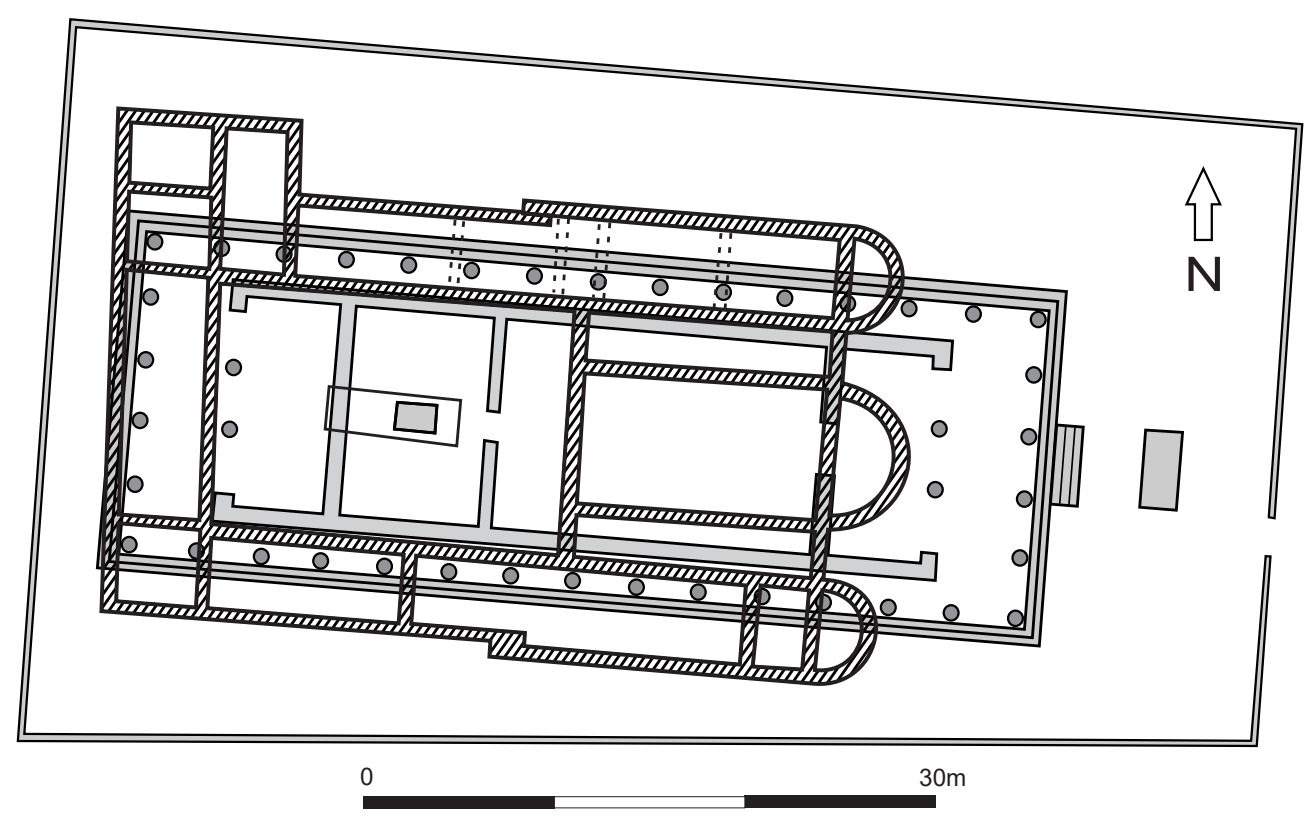

16. Temple (marked in grey) and church (hatched) at Dora (Drawing: M. Burdajewicz; based on: Dauphin 1999: Figs 1,3).

also a place visited by pilgrims going to or from Jerusalem. However, the history of the site goes back to the Iron Age, the seventh to sixth century $\mathrm{BC}$ at least. At that time, according to Claudine Dauphin, ${ }^{34}$ a shrine of Apollo was established, which consisted of a rock-cut grotto and a simple shrine (oikos), measuring 14 x 6m, with a cult statue and sacred table. In the late fifth or early fourth century $\mathrm{BC}$ the precinct was enlarged and a new colonnaded Doric temple situated on a raised podium was built (Fig. 16). The temple, measuring $25 \times 45 \mathrm{~m}$, consisted of a stoa, a central hall (cella), and the adyton.

The earliest church was built at that spot during the end of the fourth century, and reconstructed on the same plan in the late fourth or early fifth century. It was a typical basilical church $(14.5 \times 25 \mathrm{~m})$ divided into a nave (ending with an external apse) and two aisles. At the end of the southern aisle a tomb of two anonymous saints was located. To the north and south of the church there were two additional aisles ending with external apses, which probably served as an ambulatorium. The northern external aisle was divided into four rooms: a paved vestibule, antechamber, baptismal piscine and room with raised chancel area for celebration of the Eucharist. The church was accessible from a stone-paved atrium surrounded with porticoes. Beneath the courtyard a large plastered cistern was found. Two towers may have flanked atrium on the west.

The church was destroyed in the seventh century and never rebuilt.

\footnotetext{
${ }^{34}$ Dauphin 1999: 407.
} 


\section{Caesarea}

Caesarea (commonly known today as Maritima), was one of the most important achievements of Herod the Great, a strongly Hellenized king. On the site of an old Hellenistic settlement, called Straton's Tower, the king built - in 22-10/9 BC - a completely new city following the best Hellenistic town-planning principles. The city was named Caesarea to honor Herod's patron in Rome, emperor Caesar Augustus. Moreover, Herod also built a temple dedicated to goddess Roma and to deified Augustus (Fig. 17).

The temple was built on a platform (sized 90m east-west, $100 \mathrm{~m}$ north-south, and $11.5 \mathrm{~m}$ high), to the east of the inner harbor. The builders took advantage of the natural ridge of bedrock, which had been enlarged with retaining walls and filled with earth. The preserved parts of the substructure represent a podium measuring $28.5 \times 46.2 \mathrm{~m}$. The temple was probably surrounded by a colonnade and had a colonnaded porch on the west. ${ }^{35}$

The temple was probably dismantled around $\mathrm{AD} 400$, although there is no proof of any purposeful destruction.

Around $\mathrm{AD} 450$ some structures were built on a part of the platform, however the character of this new building complex remains unknown.

After the intermediate phase, by $c$. 490/500, these structures were dismantled and on the site a new sacred structure was built, namely an octagonal church-martyrion of an unknown martyr. The church consisted of two concentric octagons inscribed within two concentric squares, which were divided into rooms (chapels, and/or storerooms for liturgical equipment). The outer octagon (39m in diameter) consisted of the walls of the church, while the inner octagon had colonnade with Corinthian capitals separating the ambulatory and the central nave. In the very center of the octagon a rectangular foundation probably of a martyr shrine (reliquary) were found. In the next phase an apse was added for the Eucharistic celebrations.

The church was accessible from the west by means of a monumental staircase flanked on either side by six elongated vaults.

The church was destroyed, like many others buildings in Palestine, in the earthquake of 749 .

\section{RAMET EL-KHALIL/MAMRE}

This site identified with biblical Elonei ('oaks of') Mamre is located about 3km north of Hebron. Its localization has always been commonly associated with the dwelling place of Patriarch Abraham, and where the three Angels revealed themselves to him (Gen. 13: $18 ; 18: 1-8 ; 23: 19)$. It was probably king Herod who sponsored the erection of a sacred precinct in this place (Fig. 18). The excavations conducted there have revealed remains of a large enclosure (about 39 x 65m). ${ }^{36}$ Apparently, it was entirely paved with large stones; part of this pavement has been preserved along the southern wall. However, it remains

\footnotetext{
${ }^{35}$ Holum 2008: 1666.

${ }^{36}$ On the excavations see: Mader 1957; Magen 2003; see also: Bagatti 2002: 73-75.
} 


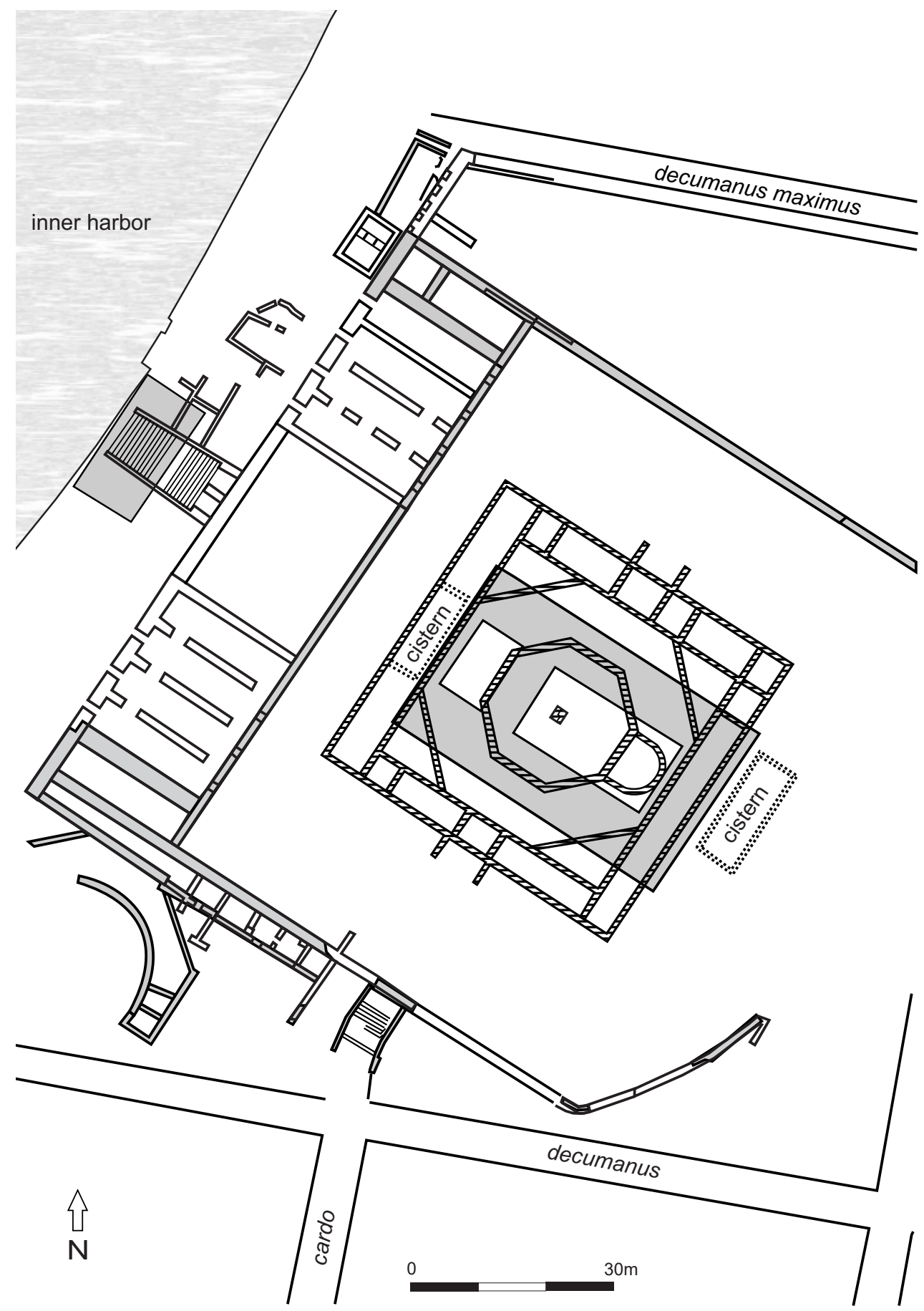

17. Herodian temple to Roma and Augustus (marked in grey) and the octagonal church (hatched) at Caesarea (Drawing: M. Burdajewicz; based on: Holum 2008: 1666-1667). 

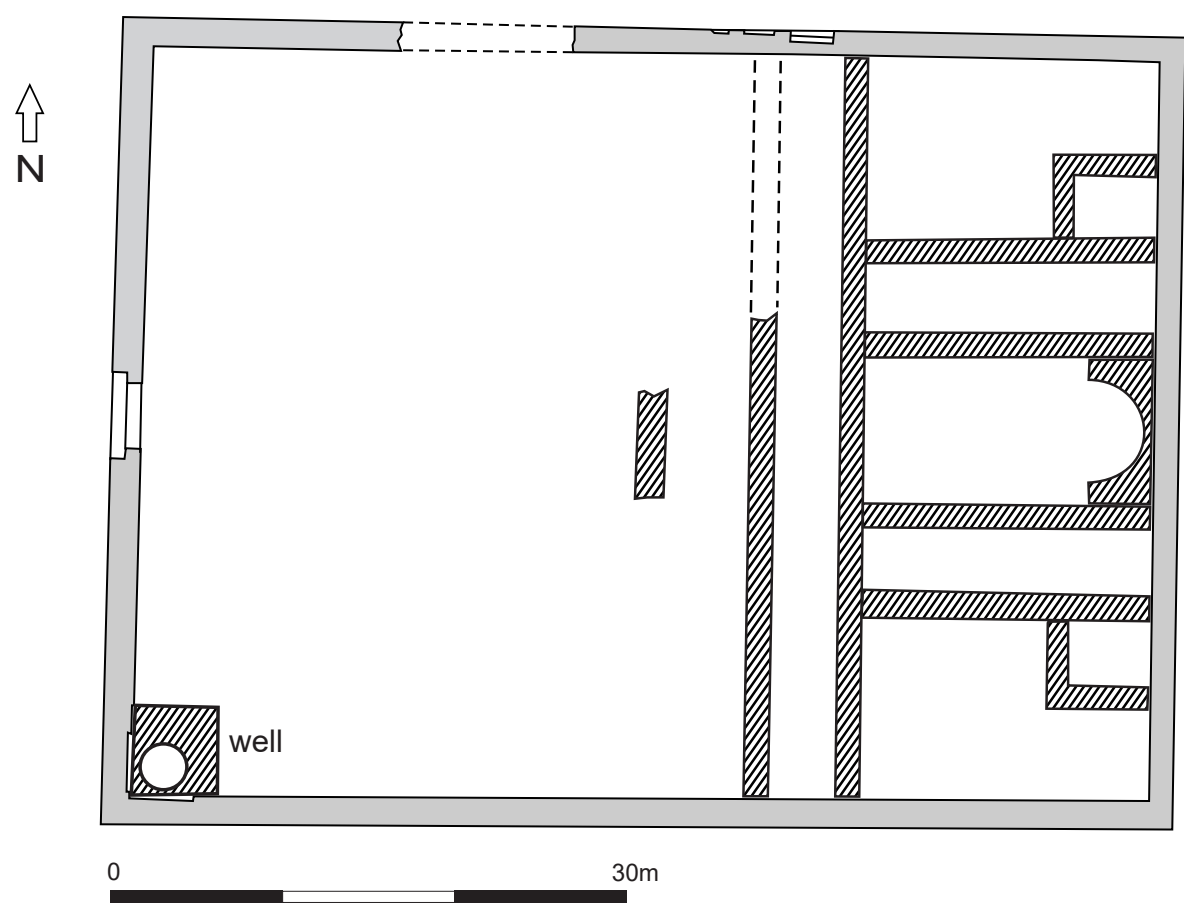

18. Cultic precinct (marked in grey) and church (hatched) at Mamre (Drawing: M. Burdajewicz; based on: Magen, Kagan 2012: Fig. 278.2).

unclear whether any structure (temple?) was built inside the enclosure. One may suppose that at least an altar stood in its center.

According to the excavator, the planning, architectural style, building methods and the characteristics of stone ashlars (with drafted margins) used for construction of the walls, are very similar to the Herodian structures such as Machpelach Cave (Hebron) and Temple Mount in Jerusalem. ${ }^{37}$ It is therefore highly probable that the enclosure at Mamre was erected during the reign of king Herod (and on his order) or shortly after his death.

The anonymus Bordeaux Pilgrim accounts: Here a basilica of wondrous beauty has been built by the command of Constantine (Itin. Burd. 599, 4-5). It seems interesting to quote here Sozomen (Historia Ecclesiastica II, 4.1-8), who describes the site before the building of the church:

Here the inhabitants of the country and of the regions round Palestine, the Phoenicians, and the Arabians, assemble annually during the summer season to keep a brilliant feast (...) this feast is diligently frequented by all nations: by the Jews, because they boast of

${ }^{37}$ Magen 2003: 254. 
their descent from the patriarch Abraham; by the Pagans, because angels there appeared to men; and by Christians, because He who for the salvation of mankind was born of a virgin, afterwards manifested Himself there to a godly man. This place was moreover honored fittingly with religious exercises. Here some prayed to the God of all; some called upon the angels, poured out wine, burnt incense, or offered an ox, or he-goat, a sheep, or a cock (...).

Unfortunately, the mother-in-law of the emperor once visited the site for prayer and then related to Constantine of what was being done there. The emperor ordered the demolition of the altar and carved images, and the erection of a 'church worthy of so ancient and so holy a place'. From Eusebius (Vita Constantini 3.51-53) we know that the church was dedicated to the Holy Trinity.

The church was built in the eastern part of the Herodian precinct. It had a basilical plan $(20 \times 16 \mathrm{~m})$ with an internal apse, central nave and two lateral aisles. Two rows of three columns separated the nave from the aisles. Two small rectangular rooms $(5.1 \times 3.9 \mathrm{~m})$ were accessible from the eastern parts of the aisles. The space to the north and south of the church was occupied by two small courtyards. The church probably also had a narthex. ${ }^{38}$ The archaeological evidence does not permit to ascertain when in fact the church was constructed and when it was abandoned or destroyed.

\section{Jerusalem/Aelia CAPitolina}

Finally, a short comment about Jerusalem. In AD 130 emperor Hadrian decided to rebuild the ruined city as a Roman colony named Aelia Capitolina, destined for his legionaries and colonists. The new city was built according to Roman town-planning principles. Among other things, a Capitoline temple was erected there. The location of the temple has been a matter of debate. At present, however, there is a common agreement that it was built on a site above the northern side of the colony's forum, that is, on the Golgotha site. ${ }^{39}$

The excavation conducted in the Church of the Holy Sepulcher by Virgilio Corbo allowed him to reconstruct the outlines of the Hadrianic temple (Fig. 19). ${ }^{40}$ It stood on an elevated podium accessible directly from the cardo maximus on the east. The building itself $(37 \times 41 \mathrm{~m})$ was surrounded by the colonnade on its three sides and divided inside into three cellae. However, that tri-partite division has not been archaeologically proved. ${ }^{41}$ Behind the temple, to the west, Corbo has located a statue of Venus/Aphrodite, exactly on the site of the tomb of Jesus.

The fate of the temple, its violent and sudden dismantling in AD 325/6, is well known thanks to Eusebius' account (Vita Constantini 3.25-40). Archaeological works have permitted to reconstruct the Constantine's church complex as consisting of eastern atrium

\footnotetext{
${ }^{38}$ Magen, Kagan 2012: 178-180.

${ }^{39}$ Belayche 1997; 2001: 142-149.

${ }^{40}$ Corbo 1982: P1. 68.

${ }^{41}$ Belayche 2001: 146.
} 


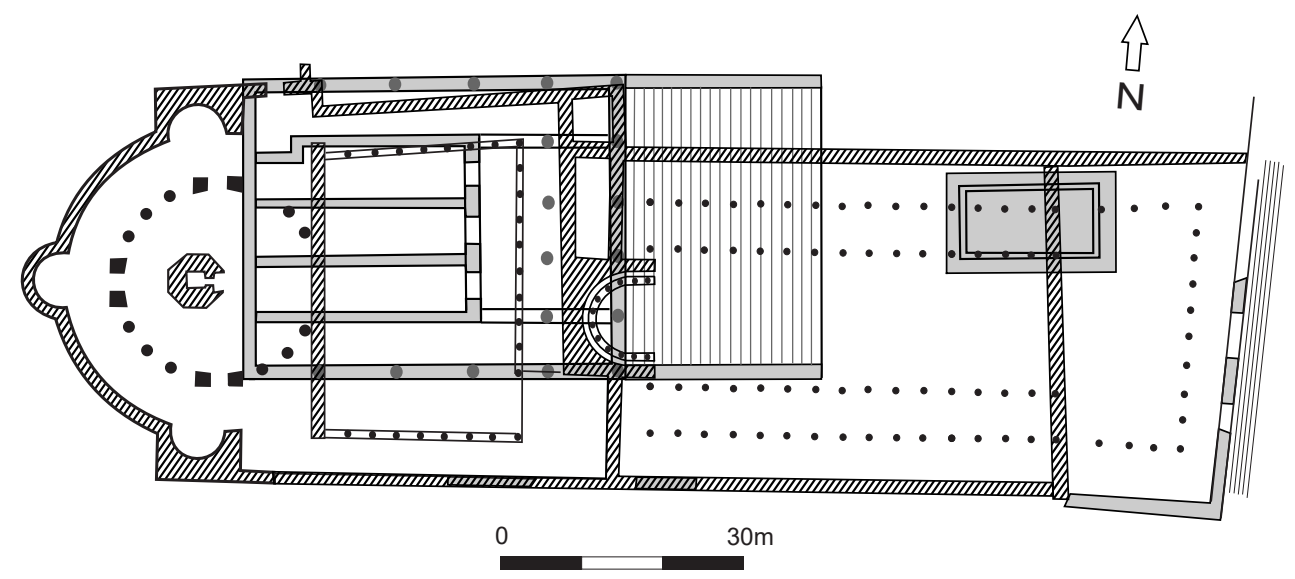

19. Temple of Venus (marked in grey) and the Church of the Holy Sepulchre (hatched) at Jerusalem (Drawing: M. Burdajewicz; based on: Corbo 1982: P1. 68; Patrich 1993: 102).

of the basilica, the basilica itself, with four rows of columns ('Martyrion'), the Holy Garden ('Triportico'), the rotunda ('Anastasis') with the tomb of Jesus. ${ }^{42}$

\section{SUMMARY}

The excavations at Sussita and the survey of archaeological evidence from some other sites have shown that the issue of the transformation of pagan temples into churches is rather complex. In the case of Palestine, this phenomenon is not homogenous and at each site different reasons and circumstances guided the builders of a given church.

At Sussita, the builders of the NWC made good use of the abandoned temple, the walls of which were extensively reused. Doubtlessly, the well preserved walls of the temenos and the temple itself constituted from the economical point of view a good opportunity for undertaking the erection of a new building in this place. There is no archaeological proof that the erection of the church over the remains of the pagan temple was a deliberately symbolic gesture signifying the victory of Christianity over Paganism..$^{43}$ In our opinion it was rather utilitarian, a more profitable reuse of already existing structures.

At Sepphoris the situation is not quite clear. The remains of the temple building are very poorly preserved, and there is no evidence that some of the walls of this structure could be reused as parts of the church's structure. It was probably just a more or less ruined and empty space in the city and therefore accessible for a new building project.

At Beth Shean and Caesarea, the churches were built on a central plan, which means that they could not faithfully follow the outlines of the earlier structures. Their location on the ruins of earlier temples resulted from the very character of the place. In both cases

\footnotetext{
${ }^{42}$ Patrich 1993: 105-108.

${ }^{43}$ Segal 2004: 24.
} 
the churches were built in the prominent and the most suitable place, on a high tell (Beth Shean) and on a high, partially artificial platform (Caesarea). Therefore, they easily dominated the landscape, and were well visible from a distance.

A common feature for all these sites, namely Sussita, Sepphoris, Beth Shean and Caesarea, is a chronological gap between the desertion of a temple and erection of a church. There is no immediate reuse of the dismantled temples. We may assume that in terms of religious conflict, Paganism versus Christianity, the building of a church on a place abandoned and lying in ruins since two, three or even more centuries, was not a very spectacular phenomenon.

The above examples stand in strong contrast to the accounts of Eusebius, Sozomen and Mark the Deacon, according to which in Jerusalem and in Gaza the churches were built immediately after the pagan temples and were dismantled down to the ground.

Jerusalem/Aelia Capitolina, one of the cities which were relatively early transformed into a Christian city, constitutes a special case. The aim of building a basilica in the Holy City was first of all to commemorate the place of the tomb of Christ. The temple of Venus in Jerusalem had to be completely dismantled to make way for a church. In the course of this action a tomb was discovered that was believed to be the tomb of Jesus. The ruling elite, including the emperor Constantine I himself, were engaged in the quest for the Christian holiest places. Similar activity by the emperor concerned the Church of the Nativity in Bethlehem, the Eleona on the Mount of Olives and Mamre, discussed above. All these sites appear to be an exception to the process of temple destruction/transformation into churches which took place centuries later in other regions and cities in Palestine.

We have presented above seven known examples of the phenomenon of reusing the pagan cult places for building churches. Except for the countryside site of Mamre and the coastal Dora, other examples are from large urban centers. Taking into consideration the fact that most of the regions and cities in Roman-period Palestine had pagan temples, ${ }^{44}$ it is rather surprising that in the 'cradle of Christianity' only such a small number of pagan temples were in one way or another affected by the process of Christianization. Thus, it seems to be an important fact to assess the significance of the discoveries in Sussita.

\section{Acknowledgments}

The present paper is part of the project financed from the resources of the Polish National Science Centre, decision: DEC-ODW/1/2012/07/BHS3/02378.

\section{References}

Avigad, N. 1950-1951: The Rock-carved Façades of the Jerusalem Necropolis, IEJ 1/2, 96-106

Bagatti, B. 2002: Ancient Christian Villages of Judaea and the Negev, SBF Collectio Minor 42 , Jerusalem

\footnotetext{
${ }^{44}$ Belayche 2001; Bar 2008: 279, with references.
} 
Bar, D. 2008: Continuity and Change in the Cultic Topography of the Late Antique Palestine, [in:] Hahn, J., Emmel, S., Gotter, U. (Eds), From Temple to Church: Destruction and Renewal of Local Cultic Topography in Late Antiquity, Religions in the Graeco-Roman World 163, Leiden, 275-298

Bayliss, R. 2005: From temple to church: converting paganism to Christianity in Late Antiquity, Minerva (L) 16/5, 45-47

Belayche, N. 1997: Du Mont du Temple au Golgotha: le Capitole de la colonie d'Aelia Capitolina, RHR 214/4, 387-413

Belayche, N. 2001: Iudaea-Palaestina: The Pagan Cults in Roman Palestine (Second to Fourth Century), Religion der römischen Provinzen I, Tübingen

Busine, A. (Ed.) 2008: Religious Practices and Christianization of the Late Antique City (4th-7th cent.), Religions in the Graeco-Roman World 182, Leiden-Boston

Corbo, V.C. 1982: Il Santo Sepolcro di Gerusalemme. Aspetti archeologici dalle origini al periodo crociato, SBF Collectio Maior 29/1-3, Jerusalem

Dauphin, C. 1999: From Apollo and Asclepius to Christ: Pilgrimage and Healing at the Temple and Episcopal Basilica of Dor, LibAnn 49, 397-430

Deichmann, F.W. 1939: Frühchristliche Kirchen in antiken Heiligtümern, JDAI 54, 105-136

Emmel, S., Gotter, U., Hahn, J. 2008: "From Temple to Church": Analysing a Late Antique Phenomenon of Transformation, [in:] Hahn, J., Emmel, S., Gotter, U. (Eds), From Temple to Church: Destruction and Renewal of Local Cultic Topography in Late Antiquity, Religions in the Graeco-Roman World 163, Leiden-Boston, $1-22$

Fitzgerald, G.M. 1931: Beth-Shan Excavations 1921-1923: The Arab and Byzantine Levels, Publications of the Palestine Section of the Museum of the University of Pennsylvania III, Philadelphia

Foerster, G. 1995: Masada V: Art and Architecture, Jerusalem

Fowden, G. 1978: Bishops and temples in the eastern Roman empire 320-435, JTS XXIX/1, 53-78

Hahn, J., Emmel, S., Gotter, U. (Eds) 2008: From Temple to Church: Destruction and Renewal of Local Cultic Topography in Late Antiquity, Religions in the Graeco-Roman World 163, Leiden-Boston

Holum, K. 2008: The Combined Caesarea Expeditions Excavations, [in:] NEAEHL 5, 1665-1668

Lavan, L. 2011: The End of the Temples: Towards a New Narrative?, [in:] Lavan, L., Mulryan, M. (Eds), The Archaeology of Late Antique 'Paganism', Late Antique Archaeology 7, Leiden-Boston, xv-lxv

Mader, A.E. 1957: Mambre: Die Ergebnisse der Ausgrabungen im Heiligen Bezirk Râmet el-Halîl in Sudpalästina 1926-1928, Freiburg im Breisgau

Magen, Y. 2003: Mamre: A Cultic Site from the Reign of Herod, [in:] Bottini, G.C., Segni, L. Di, Chrupcała, D. (Eds), One Land - Many Cultures. Archaeological Studies in Honour of Stanislao Loffreda OFM, SBF Collectio Maior 41, Jerusalem, 245-257 
Magen, Y., Kagan, E.D. 2012: Corpus of Christian Sites, [in:] Hashahar Malka, A. (Ed.), Christians and Christianity I: Corpus of Christian sites in Samaria and Northern Judea 2, Judea \& Samaria Publications 14, Jerusalem, 93-325

Mazar, A. 2006: Beth-Shean from the Late Bronze Age IIB to the Medieval Period: A Summary, [in:] Mazar, A., Excavations at Tell Beth-Shean 1989-1996 I: From the Late Bronze Age IIB to the Medieval Period, Jerusalem, 26-47

Mazor, G. 2008: The Hellenistic to Early Islamic Periods: The Israel Antiquities Authority Excavations, [in:] NEAEHL 5, 1623-1636

McKenzie, J. 1990: The Architecture of Petra, Oxford

Młynarczyk, J. 2004: Pottery Repport (Hippos-Sussita 2004), [in:] Segal, A. et al., Hippos-Sussita. Fifth Season of Excavations, September-October 2004 and Summary of All Five Seasons (2000-2004), Haifa, 140-163

Młynarczyk, J., Burdajewicz, M. 2001: The North-West Church Complex, [in:] Segal, A.,

Młynarczyk, J., Burdajewicz, M., Hippos (Sussita). Second Season of Excavations, July 2001, Haifa, 7-13

Młynarczyk, J., Burdajewicz, M. 2002: Exploration of the North-West Church Complex [area NWC and OPB] in 2002, [in:] Segal, A. et al., Hippos-Sussita. Third Season of Excavations, July 2002, Haifa, 15-28

Młynarczyk, J., Burdajewicz, M. 2003: North-West Church (NWC) Complex, [in:] Segal, A. et al., Hippos-Sussita. Fourth Season of Excavations, June-July 2003, Haifa, 24-33

Młynarczyk, J., Burdajewicz, M. 2004: The North-West Church (NWC), [in:] Segal, A. et al., Hippos-Sussita. Fifth Season of Excavations, September-October 2004 and Summary of All Five Seasons (2000-2004), Haifa, 52-72

Młynarczyk, J., Burdajewicz, M. 2005: North-West Church Complex (NWC), [in:] Segal, A. et al., Hippos-Sussita. Sixth Season of Excavations, July 2005, Haifa, $32-50$

Młynarczyk, J., Burdajewicz, M. 2006: North-West Church Complex (NWC), [in:] Segal, A. et al., Hippos-Sussita. Seventh Season of Excavations, July 2006, Haifa, $47-59$

Młynarczyk, J., Burdajewicz, M. 2013: The Northwest Church Complex, [in:] Segal, A. et al., Hippos-Sussita of the Decapolis: The First Twelve Seasons of Excavations 2000-2011 I, Haifa, 194-217

Netzer, E. 1981: Greater Herodium, Qedem 13, Jerusalem

Netzer, E. 1999: Die Paläste der Hasmonäer und Herodes’ des Großen, Mainz a/Rhein

Nocera, D. 2013: The Round Church at Beth Shean, Expedition 55/1, 16-20

Patrich, J. 1993: The Early Church of the Holy Sepulchre in the Light of Excavations and Restoration, [in:] Tsafrir, Y. (Ed.), Ancient Churches Revealed, Jerusalem-Washington D.C., 101-117

Peleg, O., Rozenberg, S. 2008: Stuccowork in the Herodian Palaces, [in:] Rozenberg, S., Hasmonean and Herodian Palaces at Jericho, Final Reports of the 1973-1987 Excavations IV: The Decoration of Herod's Third Palace at Jericho, Jerusalem, 475-522 
Peleg-Barkat, O. 2011: The Introduction of Classical Architectural Decoration into Cities of the Decapolis: Hippos, Gadara, Gerasa, and Scythopolis, ARAM Period. 23, 425-445

Rowe, A. 1930: The Topography and History of Beth-Shan I, Publications of the Palestine Section of the Museum of the University of Pennsylvania I, Philadelphia

Segal, A. 2004: Hippos-Sussita of the Decapolis, Minerva (L) 15/5, 23-25

Segal, A. 2013: Hellenistic Sanctuary, [in:] Segal, A. et al., Hippos-Sussita of the Decapolis. The First Twelve Seasons of Excavations 2000-2011 I, Haifa, 128-147

Vörös, G. 2015: Machaerus II. The Hungarian Archaeological Mission in the Light of the American-Baptist and Italian-Franciscan Excavations and Surveys, Final Report 1968-2015, Milano

Weiss, Z. 1993: Sepphoris, [in:] NEAEHL 4, 1324-1328

Weiss, Z. 2008: Sepphoris, [in:] NEAEHL 5, 2029-2035

Weiss, Z. 2010: From Roman temple to Byzantine Church; a preliminary report on Sepphoris in transition, JRA 23, 197-218

Weiss, Z. 2015: Zippori, Excavations and Surveys in Israel 127, http://www.hadashot-esi. org.i1/report_detail_eng.aspx?id=22791\&mag_id=122 (accessed December 27, 2015) 


\section{ÉTUDES et TRAVAUX XXX / 2017}

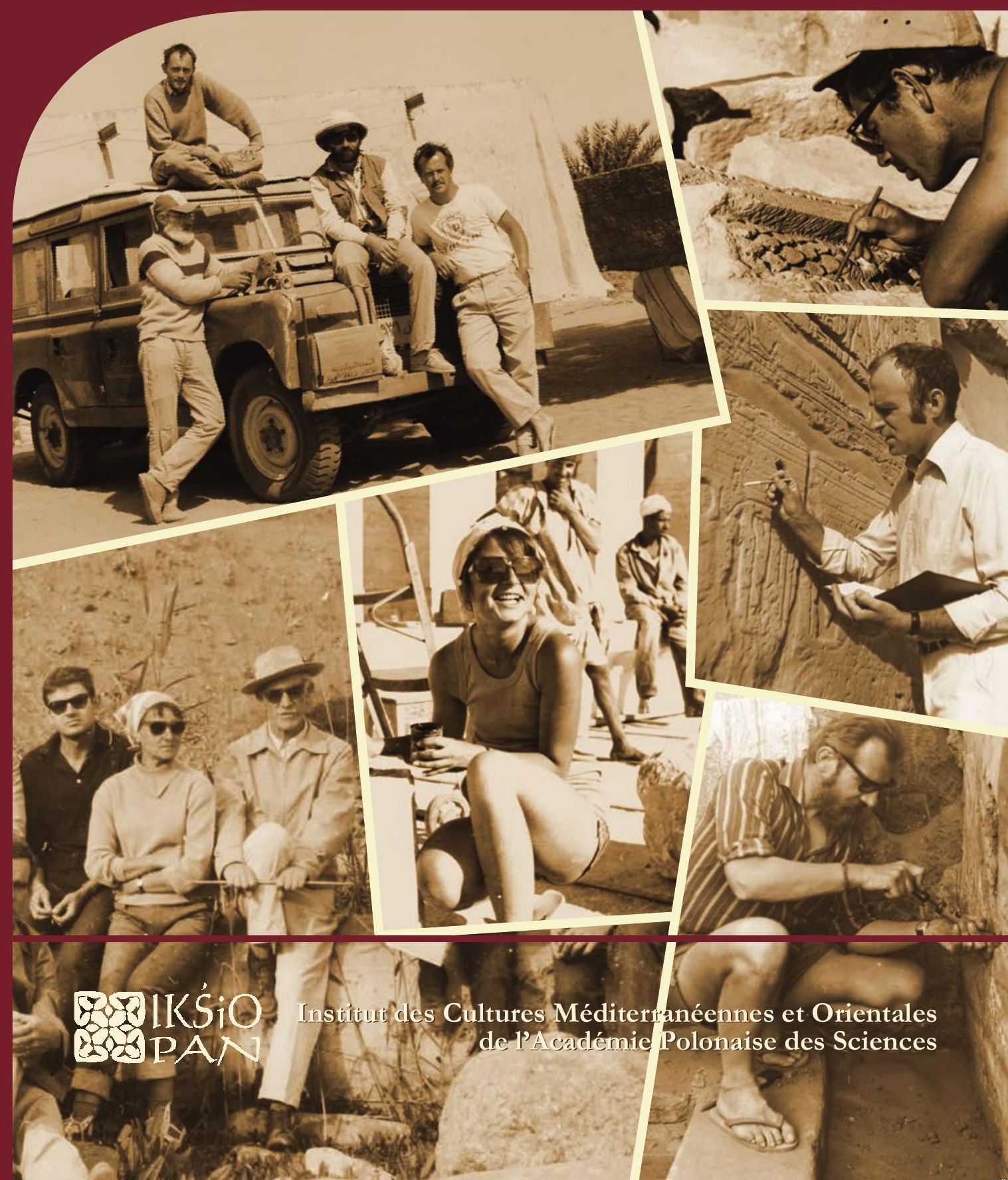




\title{
COMITÉ DE RÉDACTION SCIENTIFIQUE
}

Maciej Makowski - rédacteur en chef

Jadwiga Iwaszczuk - rédacteur et sécretaire de la rédaction

Mariusz Drzewiecki - rédacteur

Maciej G. Witkowski - rédacteur

\section{CONSEIL SCIENTIFIQUE DU JOURNAL}

M. Kobusiewicz (IAE PAS, Warszawa), E. Laskowska-Kusztal (IMOC PAS, Warszawa),

D. Michaelides (University of Cyprus, Nicosia),

J.Ch. Moretti (IRAA-MOM, Université de Lyon 2/CNRS),

D. Raue (Ägyptisches Museum der Universität Leipzig), P. Reynolds (ICREA, Barcelona),

D. Welsby (British Museum, London)

\section{COMITÉ SCIENTIFIQUE DE LECTURE}

J. Holaubek (Institut für Ägyptologie, Wien), S. Ikram (AUC, Cairo),

K. Innemée (Universiteit Leiden), J. McKenzie (Faculty of Oriental Studies, University of Oxford),

N. Strudwick (University of Cambridge), A. Loprieno-Gnirs (Universität Basel),

Ch.E. Loeben (Museen für Kulturgeschichte, Hannover), Y. Tristant (Macquarie University, Sydney),

V.W.J. van Gerven Oei (University of Aberdeen), A. Peignard-Giros (HiSoMA-MOM, Université de Lyon 2/CNRS), J.A. Ostrowski, E. Papuci-Władyka, J. Śliwa (IA JU, Kraków), R. Czerner (WUST, Wrocław), A. Ćwiek (IA AMU, Poznań), M. Wiewióra (IA NCU, Toruń), K. Domżalski

(IAE PAS, Warszawa), K.O. Kuraszkiewicz (DE FOS UW), M. Barwik, P. Bieliński, P. Dyczek, W. Godlewski, D. Ławecka, S. Rzepka, J. Żelazowski, M. Gawlikowski, J. Młynarczyk, A. Niwiński, T. Sarnowski, D. Szeląg, T. Waliszewski (IA UW, Warszawa)

\section{RÉDACTEUR THÉMATIQUE DU VOLUME \\ Barbara Lichocka}

\author{
AIDE RÉDACTION TECHNIQUE \\ Dorota Dobrzyńska, Mariusz Drzewiecki
}

REVUE DES TEXTES ANGLAIS

Jo Harper 
ÉTUDES et TRAVAUX XXX 
INSTYTUT KULTUR ŚRÓDZIEMNOMORSKICH I ORIENTALNYCH POLSKIEJ AKADEMII NAUK

\section{STUDIA i PRACE}

XXX

\section{Ro IKŚSiO \\ ESA PAN}

WARSZAWA

2017 
INSTITUT DES CULTURES MÉDITERRANÉENNES ET ORIENTALES DE L'ACADÉMIE POLONAISE DES SCIENCES

\section{ÉTUDES et TRAVAUX}

XXX

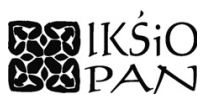

VARSOVIE

2017 
Publication scientifique financée dans le cadre du programme du Ministre de la Science et de l'Éducation Supérieure

« Programme National de Développement de l’Humanistique » pour les années 2016-2021 (projet no 3bH 150099 83)

\title{
HARODOWY PROGRAM ROZWOJU HUMANISTYKI
}

\author{
Copyright (C) \\ Instytut Kultur Śródziemnomorskich i Orientalnych PAN \\ et les Auteurs \\ Warszawa 2017
}

\author{
ISSN 2084-6762 \\ (avant $2011: 0079-3566$ ) \\ e-ISSN 2449-9579 \\ Version première en papier, imprimée en Pologne - 150 copies \\ Version électronique accessible sur \\ http://www.etudesettravaux.iksiopan.pl
}

Édition: Polskie Towarzystwo Historyczne et Wydawnictwo Neriton, Warszawa

Conception générale de couverture : J. Iwaszczuk

Photos de couverture : En haut, à gauche. Vieille Dongola 1991, S. Jakobielski

(debout à gauche), K. Pluskota (debout à droite), B. Żurawski (assis sur le camion)

et P. Wierzbicki (assis sur le camion) (de la collection de B. Żurawski)

En haut, à droite. Palmyre 1964, M. Marciniak au travail (phot. A. Dziewanowski)

Au centre. E. Laskowska-Kusztal au travail (de la collection de E. Laskowska-Kusztal)

En bas, à gauche. Tell Atrib 1962 ; de gauche : T. Biniewski, M. Marciniak, K. Kołodziejczyk,

K. Michałowski, A. Ostrasz, S. Jakobielski et S. Jasiewicz devant eux

(de la collection de IKŚSiO PAN).

En bas, à droite. Vieille Dongola 1976, S. Jakobielski nettoyant le mur (phot. M. Steinborn).

Au centre, à droite, K. Myśliwiec en train des travaux de documentation (de la collection de IKŚiO PAN) 


\section{Table des matières}

BARBARA LICHOCKA

Ergon agathon

Hartwig Altenmüller

$\mathrm{Zu}$ den Feindbildern auf den Zauberstäben des Mittleren Reiches und der Zweiten

Zwischenzeit

Nathalie Beaux

Des $m s w n s w$ de Thoutmosis III à Deir el-Bahari

Briant Bohleke, Nigel Strudwick

A Label for Opening of the Mouth Implements from the Burial of Senneferi (TT99)

and Remarks on the Ritual

Rosa Maria Bonacasa Carra, Nicola Bonacasa

Nuovi dati sugli edifici termali di Sabratha

EDWARD BROVARSKI

A Fragmentary Carrying Chair Scene in Salt Lake City, Utah

Julia Burdajewicz

Wall Painting Decoration from the North-West Church in Hippos-Sussita

of the Decapolis

Mariusz BURDAJEWICZ

From Pagan Temple to Church in Late Antiquity Palestine. A View from

Hippos-Sussita

MAREK ChlodNicki

Early Dynastic Bead Workshops at the Central Kom of Tell el-Farkha.

Patryk ChudziK, Mariusz Caban

Observations on the Architecture of the Tomb of Horhotep in Western Thebes

Krzysztof M. Cialowicz

New Discoveries at Tell el-Farkha and the Beginnings of the Egyptian State.

Amr EL-TiebI

Four Wooden New Kingdom Female Statuettes in the Egyptian Museum, Cairo 


\section{Naguib KanaWATI}

Ritual Marriage Alliances and Consolidation of Power in Middle Egypt during the Middle Kingdom

Adam Łajtar, Jolanta Mlynarczyk

A Faction Acclamation Incised on a Pithos Found Near the North-West Church at Hippos (Sussita)

Adam ŁaJTAR, Grzegorz OchaŁa

Two Private Prayers in Wall Inscriptions in the Faras Cathedral

Adam Łajtar, Anna Poludnikiewicz

Medicinal Vessels from Tell Atrib (Egypt)

JaCeK Michniewicz, Jolanta MlynarczyK

Petrographic Variability of the Fabrics of Wine Jars from Sha'ar-Ha Amakim as a Reflection of Differences in Their Provenance and Chronology

Iwona ModrzewsKa-PianetTI

Les importations d'amphores Dressel 20 en Gaule Cisalpine

Arthur SEgal

Samaria-Sebaste. Portrait of a polis in the Heart of Samaria 409

JOACHIM ŚLIWA

The Motif of a 'Blind Harper' in an Unexpected Place

MONIKA WIĘCH

Searching for the Kitchen in the Early Roman Phase of the 'Hellenistic' House at Nea Paphos (Cyprus)

Abréviations 
THE VOLUME IS PUBLISHED TO CELEBRATE

THE $60^{\text {TH }}$ ANNIVERSARY

OF THE ESTABLISHMENT OF

THE RESEARCH CENTRE FOR MEDITERRANEAN ARCHAEOLOGY POLISH ACADEMY OF SCIENCES

FOUNDED IN 1956

WHOSE MISSION IS CONTINUED BY

THE INSTITUTE OF MEDITERRANEAN AND ORIENTAL CULTURES

OF THE POLISH ACADEMY OF SCIENCES 